Proceedings of the Prehistoric Society 84, 2018, pp. 111-144 (C The Prehistoric Society. This is an Open Access article, distributed under the terms of the Creative Commons Attribution licence (http://creativecommons.org/ licenses/by/4.0/), which permits unrestricted reuse, distribution, and reproduction in any medium, provided the original work is properly cited.

doi:10.1017/ppr.2018.15 First published online 05 November 2018

\title{
A Meeting in the Forest: Hunters and Farmers at the Coneybury 'Anomaly', Wiltshire
}

\author{
By KURT J. GRON ${ }^{1 *}$, PETER ROWLEY-CONWY ${ }^{1}$, EVA FERNANDEZ-DOMINGUEZ ${ }^{1}$, DARREN R. GRÖCKE ${ }^{2}$ \\ JANET MONTGOMERY ${ }^{1}$, GEOFF M. NOWELL ${ }^{2}$ and WILLIAM P. PATTERSON ${ }^{3}$
}

The Coneybury 'Anomaly' is an Early Neolithic pit located just south-east of Stonehenge, Wiltshire. Excavations recovered a faunal assemblage unique in its composition, consisting of both wild and domestic species, as well as large quantities of ceramics and stone tools, including a substantial proportion of blades/ bladelets. We present a suite of new isotope analyses of the faunal material, together with ancient DNA sex determination, and reconsider the published faunal data to ask: What took place at Coneybury, and who was involved? We argue on the basis of multiple lines of evidence that Coneybury represents the material remains of a gathering organised by a regional community, with participants coming from different areas. One group of attendees provided deer instead of, or in addition to, cattle. We conclude that the most likely scenario is that this group comprised local hunter-gatherers who survived alongside local farmers.

Keywords: Mesolithic-Neolithic transition, isotopes, zooarchaeology, aDNA, feasting, Stonehenge landscape

The Coneybury 'Anomaly' is an isolated Early Neolithic pit. It lies in the midst of what has become one of the most celebrated archaeological landscapes in the world, the area immediately surrounding Stonehenge in Wiltshire, southern England. Figure 1 displays the immediate area around Coneybury, showing the scatter of burial mounds; Stonehenge lies $1500 \mathrm{~m}$ to the north-west, the recently discovered 'Bluestonehenge' (Parker Pearson et al. 2015) a little to the east, and the yet more recently excavated Mesolithic site at Blick Mead (Jacques et al. 2018) just beyond. Figure 1 (top) shows the major archaeological sites in the immediate area - but it must be remembered that when the Early Neolithic pit was dug at Coneybury almost none of the other sites existed; only Blick Mead

\footnotetext{
${ }^{1}$ Department of Archaeology, Durham University, South Road, Durham, UK, E-mail: k.j.gron@durham.ac.uk ${ }^{2}$ Department of Earth Sciences, Durham University, South Road, Durham, UK

${ }^{3}$ Department of Geological Sciences, University of Saskatchewan, Saskatoon, Saskatchewan, Canada
}

had been occupied, and it had apparently been abandoned for several centuries (Jacques et al. 2018).

The Early Neolithic pit was discovered in 1980 during a magnetometer survey of Coneybury Hill. The focus of the survey was a small Late Neolithic henge on the hillside. This survey produced a strong response immediately north-west of the henge bank. Figure 1 (bottom) plots the excavated areas around the henge and the pit itself. Subsequent excavation revealed a large well-cut pit with vertical sides, originally $1.9 \mathrm{~m}$ in diameter, extending to $1.25 \mathrm{~m}$ below the current surface (Fig. 2). Because it was first noted as a geophysical anomaly, this pit has become known as the 'Coneybury Anomaly' (Richards 1990, 40-61).

Our focus in the following is on the Early Neolithic pit, which we will simply term 'Coneybury'; the henge will not be further discussed. The pit was excavated in 1980 and 1981 and proved to be of Early Neolithic date, containing animal bone, ceramics, and lithic material. When initially published, only a single radiocarbon measurement was obtained, placing the deposit at 4050-3640 cal вс (Barclay 2014; Richards 1990), a rather large range encompassing the absolute 
THE PREHISTORIC SOCIETY

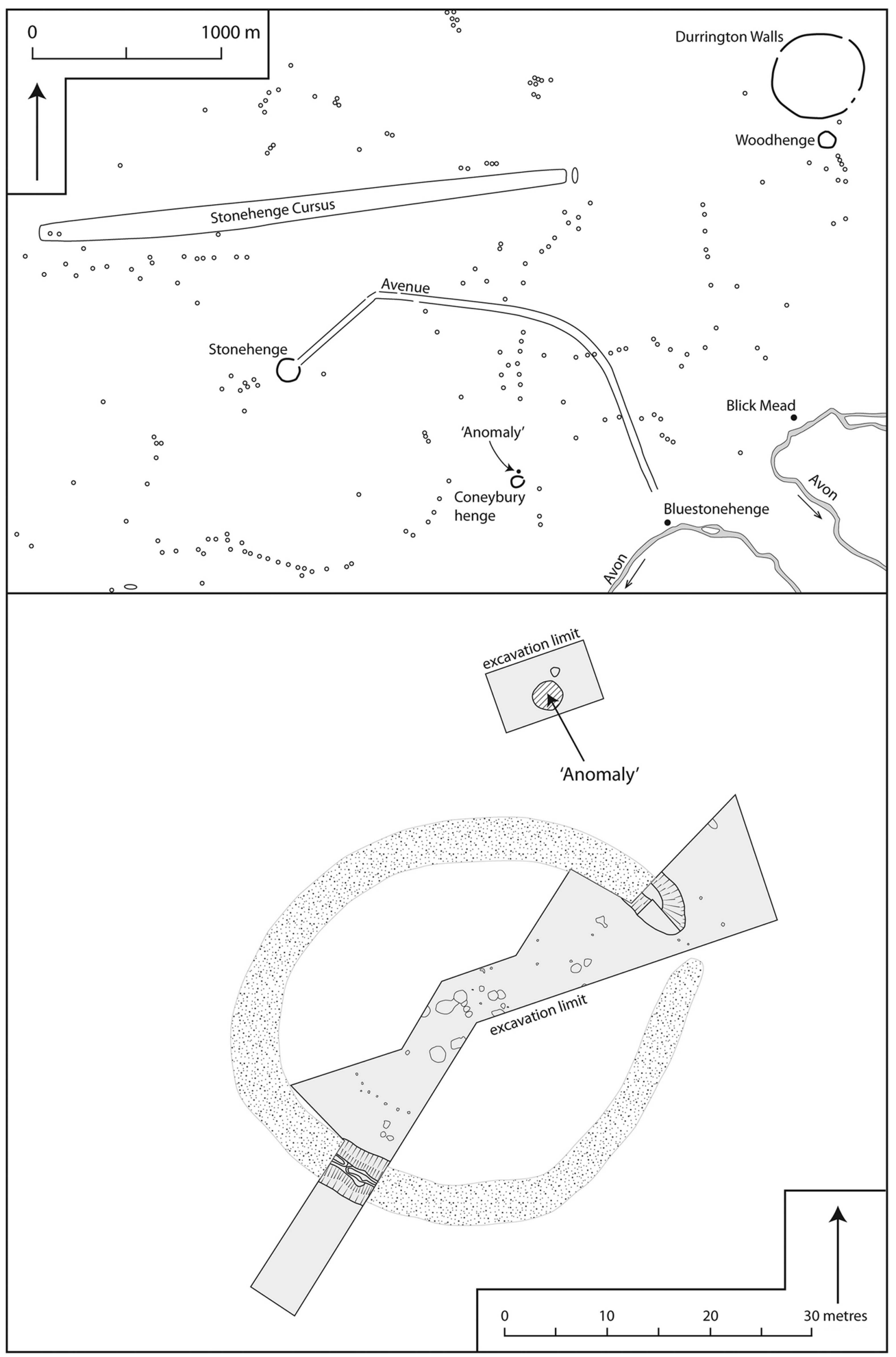

Fig. 1.

Top: the location of Coneybury in the archaeological landscape in the vicinity of Stonehenge (redrawn with amendments from Richards 1990, fig. 2). Bottom: plan of the Coneybury Henge, showing the area of excavation $\&$ the location of the Early Neolithic 'Anomaly' (redrawn with amendments from Richards 1990, fig. 97) 


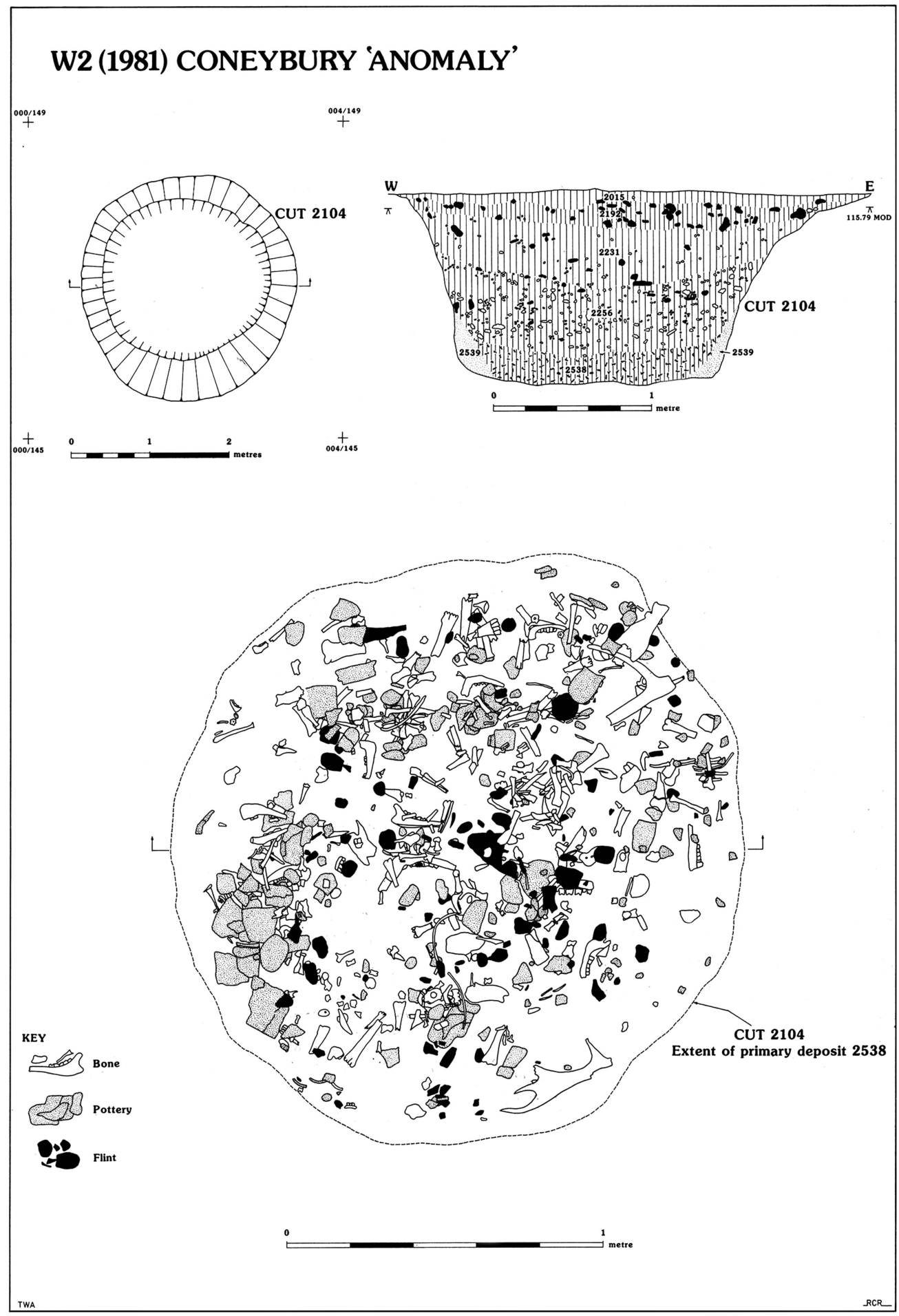

Fig. 2.

Plan \& section of the Coneybury 'Anomaly' pit (reproduced from Richards 1990, fig. 24, reprinted with permission of Historic England) 
earliest years of the Neolithic in Britain. More recently, a series of additional AMS determinations has been obtained from a variety of organic materials and animal remains. These allow the date of the deposit to be constrained to the years $3950-3790 \mathrm{cal}$ ВС (Whittle et al. 2011, 199), or 3800-3700 cal BC (Barclay 2014). The earliest traces of farming in this part of southern England date to around $4000 \mathrm{cal} \mathrm{BC}$, or just before, while the start of causewayed enclosure construction in the region is placed in the century after $3700 \mathrm{cal}$ вС (Whittle et al. 2011). Coneybury, therefore, does not date to the very first years of the Neolithic, but nonetheless pre-dates the construction of both long barrows and causewayed enclosures. The typology of the ceramic and flint industries support this dating (Cleal 2004, 173; Whittle et al. 2011, 199_ 200).

Coneybury thus dates from a crucial period in the earliest Neolithic. Since the original excavation, two developments have occurred which make a reexamination of the pit worthwhile. First, we now have a broader knowledge of the earliest Neolithic within which to contextualise the deposit, thanks to the ensuing decades of research. Secondly, there exists a greatly expanded archaeological science toolkit with which to investigate the bone material. It is generally agreed that Coneybury resulted from a single event of very limited duration (hereinafter the 'Event'). We will employ various methods to elucidate the social and economic context in which the Event occurred.

\section{CONEYBURY \& THE NEOLITHISATION DEBATE}

\section{Continuity from the Mesolithic?}

Coneybury was immediately recognised as important to the issue of how a farming culture became established in southern England. In the 1990s, the search was on for an indigenous transition from Mesolithic to Neolithic, and the importance of farming in the Neolithic was being down-played. Julian Thomas suggested that domestic animals and plants played a minor role in the economy, so that 'these people were, from an economic point of view, still formally Mesolithic' (Thomas 1993, 388; eg Tilley 1996 \& Richmond 1999 for similar views). The large number of deer in the Coneybury fauna meshed well with this view, providing evidence of a mobile lifestyle and '... the continuing use of animals and other wild resources alongside domesticated stock and cultivated cereals' (Whittle 1999, 58). Another pertinent aspect of the Coneybury pit contents was the stone tool assemblage, which contained $24 \%$ blades/bladelets (Harding in Richards 1990, 44). Between them the high frequencies of wild mammals and of blades/bladelets were argued by the excavator to show continuity from a mobile Mesolithic way of life:

\begin{abstract}
"Many aspects of the "Anomaly" suggest a more mobile emphasis, particularly the significant proportions of wild animals within the bone assemblage. Specific, if minor elements such as beaver and brown trout also suggest a continuity of emphasis on the adjacent river valley, and on an at least partly 'Mesolithic' economy. This is reflected again within the lithic assemblage which utilises a small proportion of river gravel flint and includes $24 \%$ blades/bladelets. The latter can be regarded not only as the maintenance of a technological tradition but as evidence of the continuity of an essentially mobile economy. (Richards 1990, 43)
\end{abstract}

Others have concurred that Coneybury shows a degree of continuity from the Mesolithic (e.g. Whittle 1999, 58; Richmond 1999, 20; Thomas 2013, 403). However, nearly four decades have passed since the original excavation. During this time, our understanding of the process of Neolithisation in Britain has changed, but the debate continues regarding the roles played between incoming farmers and the last foragers and what this meant (see Cummings \& Harris 2011). Both the faunal remains and the stone tools must be reconsidered in the light of current knowledge.

\section{The faunal remains}

The Coneybury faunal remains were published by Mark Maltby, whose thorough analysis revealed that cattle and roe deer dominated the assemblage (Maltby 1990; Fig. 3). At the time of publication this faunal assemblage was virtually unique in southern England. The unusually high frequency of roe deer was quite different from what was known from the major causewayed enclosures, which produced mainly domestic animals, for example Windmill Hill (Grigson 1965) and Hambledon Hill (Legge 1981). Coneybury, however, dated to the earliest phase of the Neolithic, before the causewayed enclosures, and thus provided an insight into the economy of the very first farmers.

Since the early 1990s, a number of faunal assemblages of earliest Neolithic date have been published. Serjeantson's (2011) review lists five other sites of this approximate date: Windmill Hill (pre-bank old 


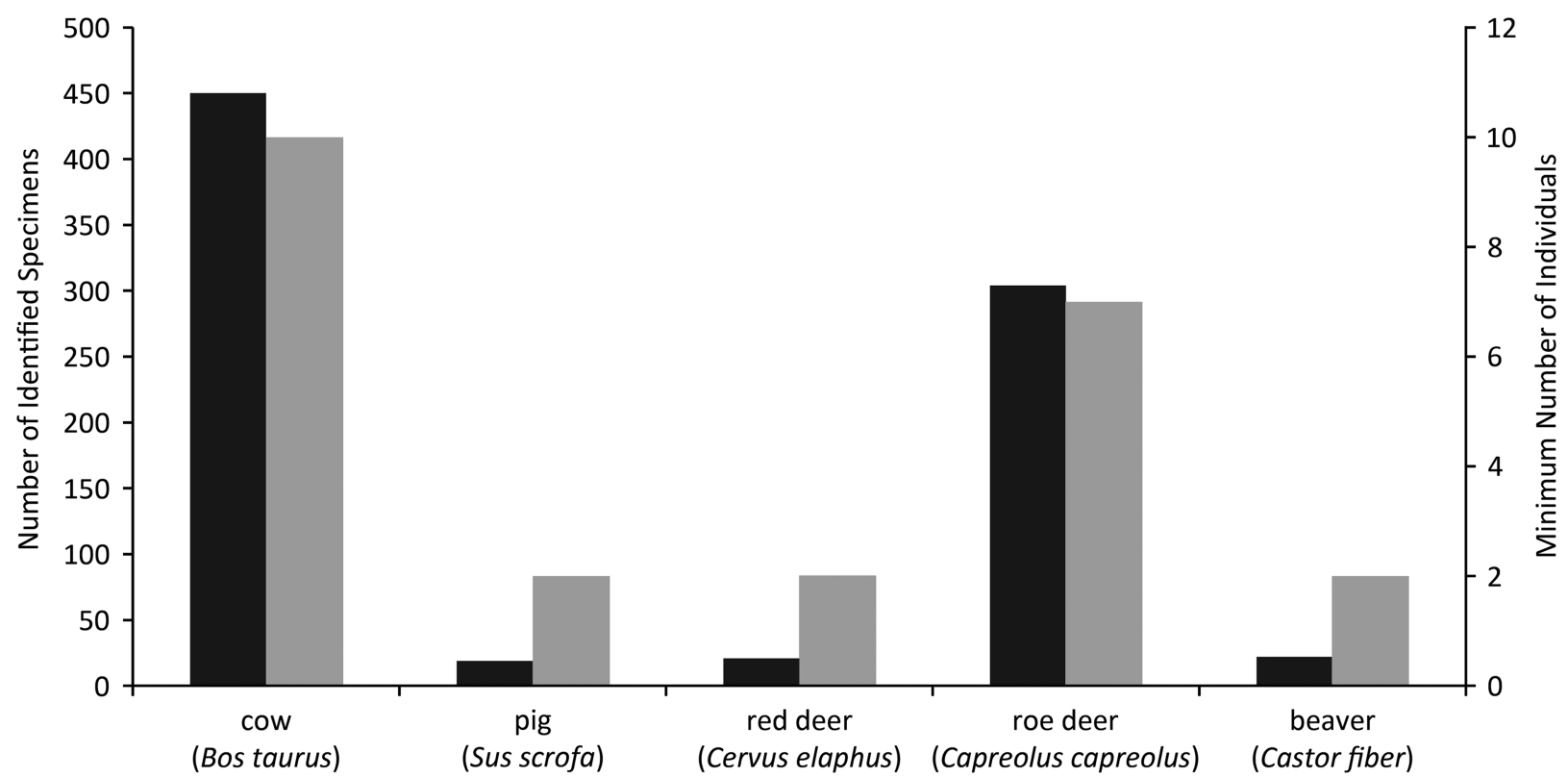

Fig. 3.

Coneybury Anomaly zooarchaeological quantification from primary deposits (Maltby 1990), omitting fish. The Number of Identified Specimens (NISP) are in black while the Minimum Number of Individuals (MNI) are in grey

land surface); Ascott-under-Wychwood (pre-barrow midden); Hazleton North (pre-barrow buried soil); Rowden; and Cherhill. To these can be added Eton Rowing Course, published since Serjeantson's review (2011). These faunal assemblages put Coneybury into a broader context. Two are less useful than the others: Rowden had a Number of Identified Specimens (NISP) of only 90 (Maltby 1991), while Cherhill's Neolithic assemblage also contained a substantial admixture of material from the underlying Mesolithic and is thus mixed (Grigson 1983). The remaining four are plotted along with Maltby's results from Coneybury in Figure 4.

The high frequency of roe deer at Coneybury is clear from Figure 4. It is also clear that none of the other sites has such a high frequency of wild mammals. Domestic animals predominate everywhere, and cattle are at $>50 \%$ on all sites except Hazleton (see Rowley-Conwy 2004 \& Serjeantson 2014 for discussions). Thomas regards the Coneybury pattern as 'a confused one, perhaps representing a formative phase in which the large-scale cattle economies associated with the causewayed enclosures after 3700 BC were only beginning to emerge' (Thomas 2013, 403). The scale of the cattle economy in the earliest Neolithic was indeed probably smaller than that suggested by the composition of the bone material from the causewayed enclosures, but the predominance of domestic cattle can hardly be doubted - in particular given their much greater meat weight, and their capacity for producing dairy products. The large number of roe deer at Coneybury is, however, an anomaly at the Anomaly.

It is not simply the number of deer that are of interest, however. The roe deer and cattle carcasses were treated differently. Using Maltby's (1990) reported Minimum Number of Element (MNE) values it is possible to calculate the derived Minimum Animal Unit (MAU) and therefore percent Minimum Animal Unit (\%MAU) statistics (Fig. 5). There is a marked difference in the butchery of the cattle and the roe deer, as Maltby (1990) showed clearly: most limbs of the cattle were removed and transported elsewhere, while those of the deer remained in the pit.

\section{The worked stone assemblage}

The worked stone assemblage included 24\% blades/ bladelets (Harding in Richards 1990, 44). The total number of blades/bladelets is unclear. This aspect of Coneybury has been less discussed than the faunal remains, but Richards (1990, 43; see quote above) 


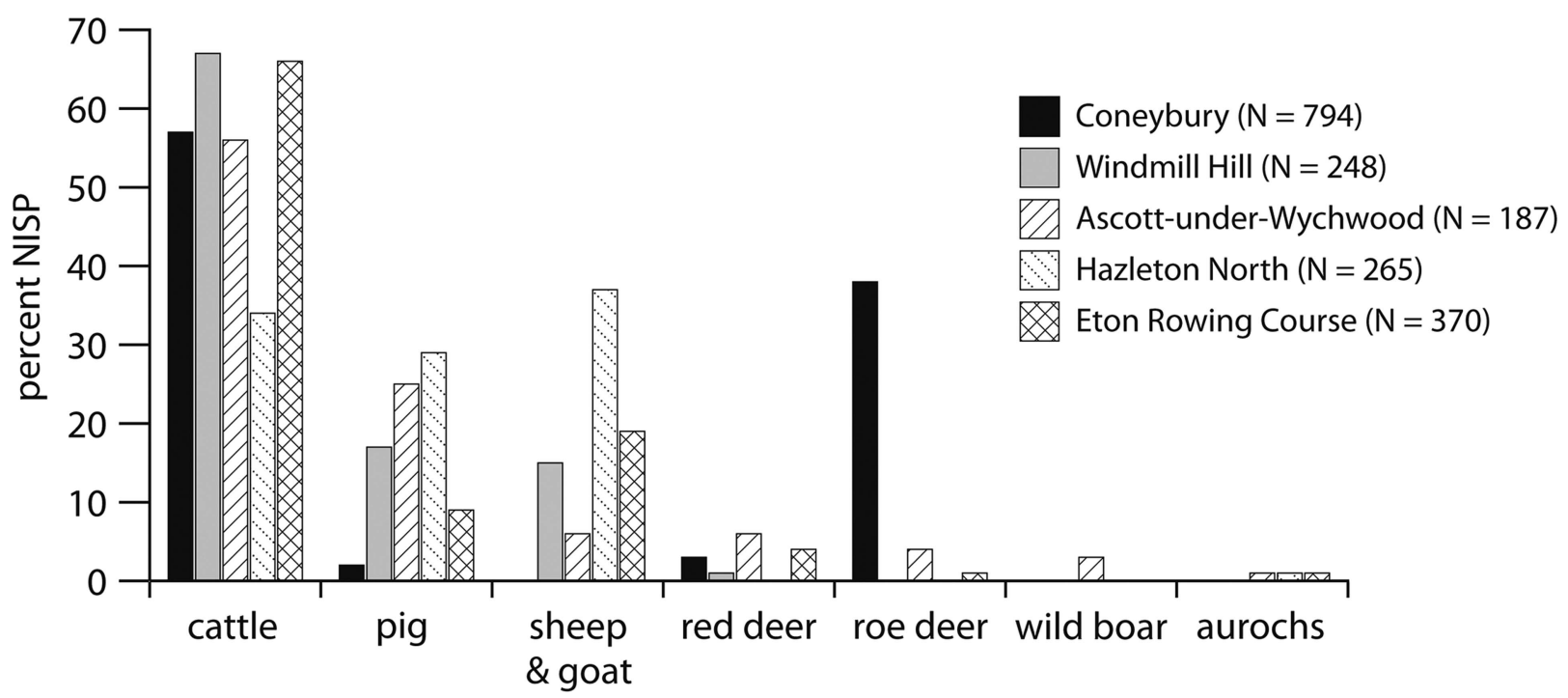

Fig. 4.

The frequency of the main mammalian species at Coneybury, compared to other assemblages of comparable date. Coneybury from Maltby (1990, table 16); Windmill Hill pre-bank old land surface, 1998 \& 1957/8 excavations summed, from Grigson (1999, tables 145.1 \& 145.2); Ascott-under-Wychwood pre-barrow from Mulville and Grigson (2007, table 8.3); Hazleton North midden below mound from Levitan (1990, table 78); Eton Rowing Course Area 6 from Jones (2013, table 5.25)

regards the blades/bladelets as indicators of continuity from the Mesolithic.

Full discussion of the Coneybury flint assemblage is beyond the scope of this paper. However, we note that work carried out on lithics since the original publication does not rule out the possibility of some continuity from the Mesolithic. Late Mesolithic assemblages contain more blades than Neolithic ones; four Mesolithic cases quantified by Ford (1987) all contain $>33 \%$, Neolithic ones $<25 \%$. Early Neolithic assemblages contain more blades than later ones, and the work of the Stonehenge Riverside Project has reaffirmed that there is a general trend for blades to decrease through the Neolithic (Chan forthcoming). Coneybury contained $25 \%$ blades/bladelets; $90 \%$ of these had butts under $4 \mathrm{~mm}$ in width, and $41 \%$ had abraded butts suggestive of platform maintenance (Harding in Richards 1990, 44, 220). Harding also examined a Late Neolithic assemblage from nearby Wilsford Down (W31); the proportion of blades is not clear, but $32 \%$ of them had butts greater than $5 \mathrm{~mm}$ in breadth, and only $4.5 \%$ had platform abrasion (Harding in Richards 1990, 220). More recently, the excavation of a buried soil under the bank at Woodhenge has yielded an assemblage approximately contemporary to that from Coneybury; this contained
$14.4 \%$ blades, of which $31 \%$ showed platform abrasion (Chan forthcoming and pers. comm., 23 May 2018). It therefore remains possible that the frequency and method of manufacture of the blade/bladelets at Coneybury represents some kind of continuity from the Mesolithic.

There has been discussion of whether Mesolithic and Neolithic stone tools might overlap in time. Much has been made of both the superimposition of Early Neolithic burial mounds on scatters of Mesolithic flints, and also the incorporation of Mesolithic flints within the actual fabric of Neolithic mounds. Both have been used to argue for continuity or overlap between the two periods. However, one recent major survey of the evidence has found that such cases are in fact rare, and are likely to be due to chance (Graf in prep.). The few documented cases have been much discussed.

Regarding superimposition, discussion has focused on three main cases: Gwernvale, Ascott-under-Wychwood, and Hazleton North. Gwernvale was the first to be published (Britnell \& Savory 1984). Numerous flints from the soil below the barrow were argued to be of Late Palaeolithic and Early and Late Mesolithic types (Healey \& Green in Britnell \& Savory 1984). One reviewer has, however, questioned this, arguing 
K.J. Gron et al. MEETING IN THE FOREST: HUNTERS \& FARMERS AT THE CONEYBURY 'ANOMALY', WILTSHIRE

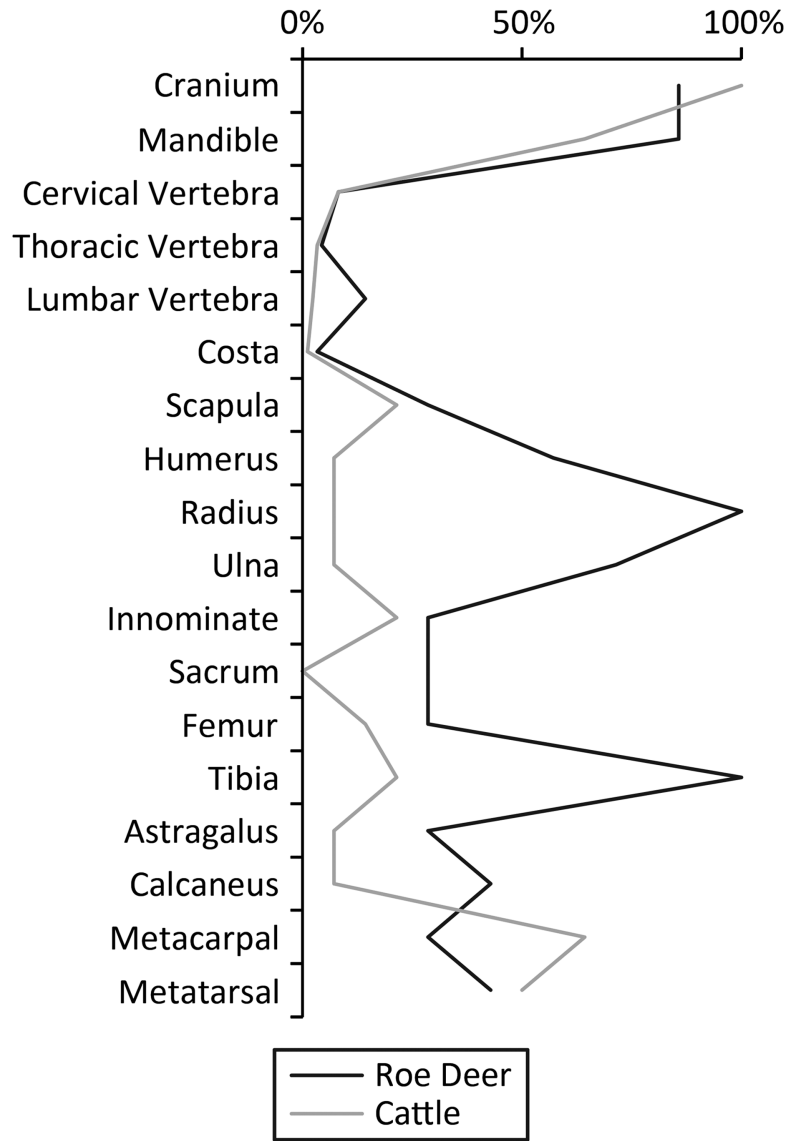

Fig. 5.

Percent MAU for roe deer \& cattle. Values calculated from MNE values in Maltby (1990) sensu Gron $(2015,724) \&$ Rowley-Conwy (1998). Certain elements omitted as per Gron $(2015,724)$

that all the flints could be Late Mesolithic (Saville 1985). Whatever the case, the original publication (Britnell \& Savory 1984) made no claim that the cairn was deliberately placed on a Mesolithic site. At Ascottunder-Wychwood, the long barrow overlies a Neolithic midden perhaps 50-100 years older than the barrow. In and around this midden were found a few Late Mesolithic flints, and many more Early Mesolithic ones (Benson \& Whittle 2007). It has been argued that the Early Mesolithic flints were deliberately collected by Neolithic people for incorporation in the Neolithic midden (McFadyen et al. in Benson \& Whittle 2007, 26, 35; McFadyen in Benson \& Whittle 2007, 351; Whittle 2010, 41). Saville (2007) has, however, argued that their presence could be due to chance, and given the difficulties that even trained archaeologists experience recovering microliths on unsieved sites, we are inclined to agree with him. Saville is himself the excavator of the third major example of superimposition, the Hazleton North long barrow (Saville 1990). This overlay a buried soil containing scatters of both Neolithic and Late Mesolithic flints, raising the possibility of chronological overlap. The distributions of the scatters were however largely separate (ibid., 153 \& fig. 163), and there was no connection between them: there were numerous refits within each scatter, but none between the two scatters (ibid., fig. 173). Saville concluded that they were therefore chronologically separated, by an unknown span of time (ibid., 14). The modes of flint working were so distinct that if the two assemblages are chronologically very close, then two quite separate populations must be supposed' (ibid., 175).

Regarding incorporation, this also occurred at Ascott-under-Wychwood: many Early Mesolithic flints were found in the north-east part of the mound. Neolithic quarry pits cut through a Mesolithic site, and the excavated material was used to construct the mound (McFadyen et al. in Benson \& Whittle 2007, $25)$. At Foulmire long barrow, incorporation has been used to argue for continuity: two areas of the mound incorporated mixed Late Mesolithic and Early Neolithic flints, argued to show a 'later fifth- and/or earlier fourth-millennium BC occupation having both Mesolithic and Neolithic attributes: in short, "mixed" or "transitional" assemblages' (Evans \& Hodder 2006, 190). This mixture however occurred in no primary contexts, and the project's flint specialist regarded the Mesolithic material as residual (Middleton in Evans \& Hodder 2006, 161).

Other cases of incorporation have not led to claims of overlap. At the open-air site of Cherhill, Neolithic ditches cut through Mesolithic layers, liberating both faunal remains and flints into the Neolithic layers (Grigson \& Pitts in Evans \& Smith 1983, 64, 84). The Neolithic mound at Addington was placed on an extensive Mesolithic flint scatter, and over 2000 Mesolithic flints were found in the barrow itself, having been in the topsoil from which the mound was built (Alexander 1961). At Green Low, typologically Mesolithic flints in the Neolithic mound were heavily patinated and had evidently been exposed for a long period before being incorporated in the mound (Manby 1965). Differential patination was also the case at the Early Neolithic open air settlement at the Eton Rowing Course, where the small quantity of 

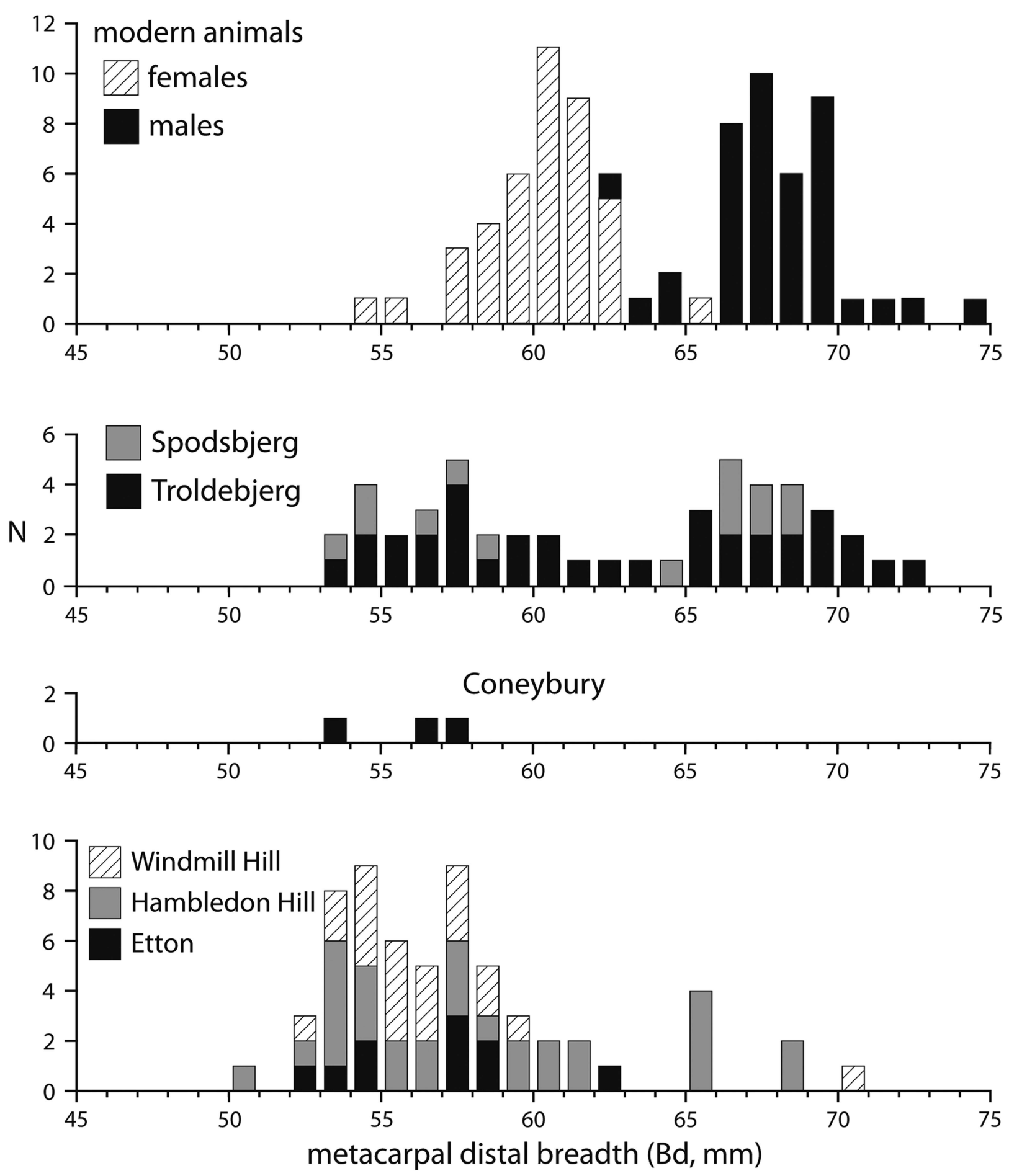

Fig. 6.

The Coneybury distal metacarpal measurements (von den Driesch 1976; from Maltby 1990, fiche table 24), compared to modern specimens of known sex (from Higham 1969, supplementary table 2.2), compared to those from Spodsbjerg \& Troldebjerg in Denmark (from Nyegaard 1985, fig. 2a), \& Windmill Hill, Hambledon Hill, \& Etton in Britain (from Grigson 1999, appx 1.1; Armour-Chelu unpublished; \& Legge 2008, table 8.28, respectively). One aurochs from Etton with a Bd of $85 \mathrm{~mm}$ (Armour-Chelu unpublished) is not plotted 


\section{K.J. Gron et al. MEETING IN THE FOREST: HUNTERS \& FARMERS AT THE CONEYBURY 'ANOMALY', WILTSHIRE}

residual Mesolithic material was visibly rolled, in contrast to that of the Neolithic (Anderson-Whymark in Allen et al. 2013, 151).

This all suggests that Mesolithic flints were not regarded as 'special' by Neolithic people, but were merely dug up or buried (were they even noticed?) during Neolithic construction projects. In the light of this, we are very aware that Coneybury appears to stand out from all the sites discussed above. However, the 'Mesolithic' blades/bladelets are in the primary pit fill, along with the Neolithic flints. Little Mesolithic activity was recorded in the area, none of it near the pit itself, so there is no obvious source from which residual Mesolithic material could be derived. There is no mention that the blades/bladelets were weathered or patinated any differently to the Neolithic material (Harding in Richards 1990, 43-4). The blades/bladelets must therefore be part of the Event. If the blades/ bladelets really do have a Mesolithic derivation, Coneybury is therefore probably the most convincing British example of material traditionally considered to be of either Mesolithic or Neolithic cultural derivation being archaeologically contemporary.

\section{Discussion}

The last 20 years have produced increasing quantities of evidence from the southern British earliest Neolithic. Except for Coneybury, these sites have suggested that the agricultural economy and way of life were dominant from the start. Domestic animals were overwhelmingly predominant (Fig. 4), and no transition is visible from the Mesolithic (RowleyConwy 2011; Serjeantson 2014). Cereals are also argued to predominate over wild plant foods (Jones \& Rowley-Conwy 2007; Bishop et al. 2010). Artefactual continuity or overlap is similarly difficult to sustain.

Are there any other sites like Coneybury? Thomas (2013, 236-40) argues that three sites show similarities: Rowden, Cannon Hill, and the Fir Tree Field shaft. The pit at Rowden however contains no 'Mesolithic' artefactual admixture (Harding in Woodward 1991), and the small faunal assemblage is entirely dominated by domestic animals, roe deer amounting to only two of the 90 specimens (Maltby in Woodward 1991). At Cannon Hill, the Neolithic pit 1 contained hardly any animal bone fragments and just a single microlith (Bradley et al. 1976). These sites might have seen some similar activities to Coneybury, but if they did they involved no 'Mesolithic' component. The shaft in Fir Tree Field contained only a few Mesolithic and Neolithic items, which were in any case stratigraphically separate (Allen \& Green 1998).

Nor can Britain's immediate neighbours provide parallels. A major survey of the Irish pit material by Smyth (2012) has not produced anything similar. Scandinavia and the Low Countries have produced none. Pit e4 below the Breton Neolithic long mound of Er Grah contained the articulated skeletons of two cattle, one probably domestic, one uncertain but possibly wild (Tresset \& Vigne 2006): a 'special' deposit but not one that resembles Coneybury.

Coneybury is thus unique in two respects: the presence of many deer and of many blades/bladelets. No other site has either of these features, far less both. While it is true that any incrementing pattern must start with a single example, until such further examples appear, any hypotheses regarding Coneybury remain very tentative, and apply to this site alone.

\section{CATTLE AGE \& SEX: DENTITION, BIOMETRY \& aDNA}

As a first step towards understanding the Coneybury Event, we consider the cattle remains to see what can be discerned about their management regime. Large cattle assemblages are available from several causewayed enclosures. These contain mostly adult females. It is generally accepted that this was because a dairy strategy was practised in Britain, in which most males were killed at a very young age (eg, Legge 1981; 2008; Halstead 1998; Serjeantson 2011; Rowley-Conwy \& Legge 2015; Halstead \& Isaakidou 2017). At the Hambledon Hill causewayed enclosure the majority of the mandibles were aged between 1.5 and 3 years. These are too young to come from old females at the ends of their milking lives; they likely represent young females, surplus to the requirements of the adult milking herd and therefore available for slaughter at this age (Legge 2008). Lipids from ceramics support the dairying hypothesis, revealing that pots were often used to contain milk (Cramp at al. 2014).

Most samples from the pre-causewayed enclosure Neolithic are, however, rather small (see Fig. 4), so age and sex studies are problematic due to small sample size. The Coneybury assemblage is the largest and provides a hitherto unique window into cattle management in the earliest Neolithic. In the following we examine first, age based on mandibular tooth 
TABLE 1: SAMPLE INFORMATION AND SAMPLE NUMBERS BY TYPE OF ANALYSIS

\begin{tabular}{|c|c|c|c|c|c|c|c|c|c|}
\hline $\begin{array}{l}\text { Specimen } \\
\text { no. }\end{array}$ & Species & Element (all teeth mandibular) & Side & Part & Age & $\begin{array}{c}\text { Bone collagen } \\
\quad(C, N, S)\end{array}$ & $\begin{array}{c}\text { Tooth enamel } \\
\quad(\mathrm{Sr})\end{array}$ & $\begin{array}{c}\text { Tooth } \\
\text { enamel } \\
(\mathrm{C}, \mathrm{O})\end{array}$ & Bone aDNA \\
\hline CM1 & Bos taurus & mandible with $\mathrm{dp} 3, \mathrm{dp} 4, \mathrm{M} 1, \mathrm{M} 2$ & $\mathrm{R}$ & symphasis-toothrow & 15-26 months & CM1CN-24 & CM1Sr-8, 9, 10 & OCM1-1, 2 & $\mathrm{CN}-24$ \\
\hline CM2 & Bos taurus & mandible with M1, unerupted M2 & $\mathrm{R}$ & toothrow-ramus & $6-15$ months & $\mathrm{CM} 2 \mathrm{CN}-18$ & $\mathrm{CM} 2 \mathrm{Sr}-7$ & OCM2 & $\mathrm{CN}-18$ \\
\hline CM3 & Bos taurus & M1 & $\mathrm{L}$ & complete tooth & & & & OCM3 & \\
\hline CM4 & Bos taurus & mandible with $\mathrm{dp} 3, \mathrm{dp} 4$ & $\mathrm{~L}$ & toothrow & $<26$ months & CM4CN-20 & & & \\
\hline CM5 & Bos taurus & mandible with $\mathrm{dp} 4$ & $\mathrm{R}$ & toothrow & $6-15$ months & $\begin{array}{l}\text { same as } \\
\mathrm{CM} 2 \mathrm{CN}-18\end{array}$ & CM5Sr-4 & & $\begin{array}{l}\text { same as } \\
\mathrm{CN}-18\end{array}$ \\
\hline CM6 & Bos taurus & mandible with $\mathrm{dp} 2, \mathrm{dp} 3, \mathrm{M} 1$ & $\mathrm{~L}$ & diastema- toothrow & & CM6CN-21 & CM6Sr-1, 2 & OCM6 & $\mathrm{CN}-21$ \\
\hline CM7 & Bos taurus & $\begin{array}{l}\text { mandible with } \mathrm{dp} 3, \mathrm{dp} 4 \text {, unerupted } \\
\text { M1 }\end{array}$ & $\mathrm{L}$ & ramus-toothrow & $<1$ month & $\mathrm{CM} 7 \mathrm{CN}-23$ & CM7Sr-3 & & $\mathrm{CN}-23$ \\
\hline CM8 & Bos taurus & mandible with dp2, dp3, dp4, M1 & $\mathrm{R}$ & toothrow-symphasis & $6-15$ months & CM8CN-15 & CM8Sr-5, 6 & & $\mathrm{CN}-15$ \\
\hline CM9 & Bos taurus & $\begin{array}{l}\text { mandible with dp2, dp3, dp4, } \\
\text { unerupted M1 }\end{array}$ & $\mathrm{L}$ & $\begin{array}{l}\text { ramus, toothrow } \& \\
\text { diastema }\end{array}$ & $<1$ month & CM9CN-16 & CM9Sr-11 & & $\mathrm{CN}-16$ \\
\hline CM10 & Bos taurus & mandible with $\mathrm{P} 4, \mathrm{M} 1, \mathrm{M} 2, \mathrm{M} 3$ & $\mathrm{~L}$ & toothrow & $3-6$ years & CM10CN-25 & $\begin{array}{l}\text { CM10Sr-17, } 18, \\
\quad 19\end{array}$ & $\begin{array}{c}\text { OCM10- } \\
1,2,3\end{array}$ & $\mathrm{CN}-25$ \\
\hline CM11 & Bos taurus & mandible & $\mathrm{R}$ & symphasis- ramus & & CM11CN-19 & & & $\mathrm{CN}-19$ \\
\hline CM12 & Bos taurus & mandible with M3 & $\mathrm{R}$ & symphasis- toothrow & $>26$ months & CM12CN-22 & CM12Sr-16 & OCM12 & $\mathrm{CN}-22$ \\
\hline MC1 & Bos taurus & metacarpal & $\mathrm{L}$ & proximal end \& shaft & & MC1CN-12 & & & \\
\hline MC2 & Bos taurus & metacarpal & $\mathrm{L}$ & proximal end \& shaft & & MC2CN-11 & & & \\
\hline MC3 & Bos taurus & metacarpal & $\mathrm{R}$ & distal shaft & & $\mathrm{MC} 3 \mathrm{CN}-13$ & & & \\
\hline MC4 & Bos taurus & metacarpal & $\mathrm{R}$ & distal shaft & & MC4CN-10 & & & \\
\hline MC5 & Bos taurus & metacarpal & $\mathrm{R}$ & proximal end \& shaft & & MC5CN-9 & & & \\
\hline MC6 & Bos taurus & metacarpal & $\mathrm{L}$ & shaft & & MC6CN-14 & & & \\
\hline MC7 & Bos taurus & metacarpal & ? & shaft & & MC7CN-8 & & & \\
\hline R1 & $\begin{array}{l}\text { Capreolus } \\
\text { capreolus }\end{array}$ & radius & $\mathrm{L}$ & proximal end \& shaft & & R1CN-4 & & & \\
\hline $\mathrm{R} 2$ & $\begin{array}{l}\text { Capreolus } \\
\text { capreolus }\end{array}$ & radius & $\mathrm{L}$ & proximal end \& shaft & & $\mathrm{R} 2 \mathrm{CN}-6$ & & & \\
\hline R3 & $\begin{array}{l}\text { Capreolus } \\
\text { capreolus }\end{array}$ & radius & $\mathrm{L}$ & proximal end \& shaft & & R3CN-5 & & & \\
\hline R4 & $\begin{array}{l}\text { Capreolus } \\
\text { capreolus }\end{array}$ & radius & $\mathrm{L}$ & proximal end \& shaft & & R4CN-7 & & & \\
\hline R5 & $\begin{array}{l}\text { Capreolus } \\
\text { capreolus }\end{array}$ & radius & $\mathrm{R}$ & proximal end \& shaft & & R5CN-3 & & & \\
\hline R6 & $\begin{array}{l}\text { Capreolus } \\
\text { capreolus }\end{array}$ & radius & $\mathrm{R}$ & proximal end \& shaft & & R6CN-1 & & & \\
\hline R7 & $\begin{array}{l}\text { Capreolus } \\
\text { capreolus }\end{array}$ & radius & $\mathrm{R}$ & distal end $\&$ shaft & & R7CN-2 & & & \\
\hline RM1 & $\begin{array}{l}\text { Capreolus } \\
\text { capreolus }\end{array}$ & mandible with M2, M3 & $\mathrm{R}$ & toothrow-ramus & $3-5$ years & RM1CN-28 & RM1Sr-14 & & \\
\hline RM2 & $\begin{array}{l}\text { Capreolus } \\
\quad \text { capreolus }\end{array}$ & mandible with $\mathrm{dp} 2, \mathrm{dp} 3$ & $\mathrm{~L}$ & symphasis- toothrow & $<1$ year & RM2CN-29 & RM2Sr-13 & & \\
\hline RM3 & $\begin{array}{l}\text { Capreolus } \\
\text { capreolus }\end{array}$ & mandible with M1, M2, M3 & $\mathrm{L}$ & toothrow to ramus & $1-2$ years & RM3CN-27 & RM3Sr-15 & & \\
\hline RM4 & $\begin{array}{l}\text { Capreolus } \\
\text { capreolus }\end{array}$ & mandible with $\mathrm{dp} 3$ and $\mathrm{dp} 4$ & $\mathrm{~L}$ & toothrow & $<1$ & RM4CN-26 & RM4Sr-12 & & \\
\hline
\end{tabular}

Cattle assigned age based on Legge (1992), deer RM1 and RM3 assigned based on Aitkin (1975), and RM2 and RM4 based on Noe-Nygaard (1987). Cattle toothwear recorded in Table S1 


\section{K.J. Gron et al. MEETING IN THE FOREST: HUNTERS \& FARMERS AT THE CONEYBURY 'ANOMALY', WILTSHIRE}

eruption and wear and sex based on biometry; and ancient DNA.

\section{Age at death}

Table 1 presents an overview of the samples analysed, listing all the analyses carried out for each mandible and postcranial element. Eight mandibles could be aged: two were perinatal; four more between 6 and 30 months; one between 3 and 6 years; and one (CM12) was indeterminate. Sample size is very small, and furthermore Coneybury is not a settlement and we do not know the reasons for which individual cattle were selected for the Event; but since the majority of the animals are immature or young adults, the pattern appears similar to that at Hambledon Hill.

\section{Sex: biometry}

Many cattle postcranial elements can be assigned biological sex by metrical means. Maltby (1990, fiche table 24) lists a number of measurements from the Coneybury cattle. We discount here the two measurements of the scapula neck, because these grow substantially even after fusion (Rowley-Conwy 2013; Fig. 6). Of the remainder of the measured bones, most are fused. The proximal metapodials and astragalus do not have fusion points, so it cannot be demonstrated that they are mature; but they do not show as much growth as the scapula neck, thus, we include them in our consideration.

Distal metacarpal is generally sexually dimorphic, and is plotted in Figure 6. The sample of modern cattle of known sex is nicely bimodal, with only a few specimens at the overlap. Neolithic examples from Troldebjerg and Spodsbjerg in Denmark are also plotted, and form a similar bimodal pattern suggesting that both sexes are present. Distal metacarpal fuses at c. 2-2.5 years of age (Silver 1969, table a), indicating that males and females survived in approximately equal numbers until at least this age. The British sites of Windmill Hill, Wiltshire; Hambledon Hill; and Etton, Cambridgeshire are in marked contrast: there are very few males. Most males were evidently being killed younger than the age of fusion. The three Coneybury specimens are similar, falling clearly in the female range (Fig. 6).

The most common element that could be measured at Coneybury was, however, the proximal metacarpal, with seven specimens. These are plotted in Figure 7.
The absence of a fusion point means that this element is rarely used in considerations of sex and, furthermore, there are no modern measurements of known males and females such as those for the distal metacarpal in Figure 6. However, Figure 7 shows that sexual determination based on the proximal end is fairly robust. Measurements are available for a large sample of Danish aurochs of known sex and they show no overlap between males and females. One sample of modern females was measured by Higham (1969) and they form a tight group as expected for just one sex. (These animals were Red Danish cows, a breed much larger than the Aberdeen Angus that provided the males and females forming the modern sample in Fig. 6, and hence relatively much larger than the Neolithic specimens). The measurements from the British causewayed enclosures cluster towards the lower end of the size range, confirming the impression that females are strongly predominant at these sites. All seven Coneybury specimens fall into the lower end of this range, and are consequently identified as females.

This approach can be applied to all the measurements listed by Maltby (1990). These are listed in Table 2, along with the available British comparatives. In every instance the Coneybury measurements fall into the main group at the causewayed enclosures; that is, the putative females. We therefore identify every one of the 18 measured bones listed in Table 2 as female. Not one male can be demonstrated metrically.

\section{Sex: ancient DNA}

Previous research has shown a highly significant correlation between morphological and genetic sex determinations in cattle postcranial archaeological remains (Svensson et al. 2008). Male and female mandibles, however, cannot be separated by metrical means. This is unfortunate because it is the mandibles that provide the best information on age at death. However, cattle mandibles may be sexed by their DNA. Nine cattle mandibular bone samples were initially selected for DNA-based sex determination, regardless of the presence or absence of teeth. Specimen CM4 was, however, not analysed, as doing so would have completely exhausted the remaining bone associated with, and connecting, the teeth. We therefore analysed eight mandibles. Materials and methods are detailed in Appendix S1. 


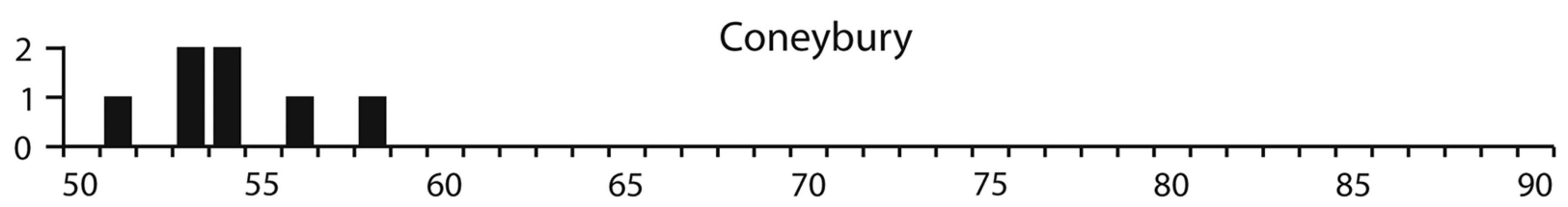

Causewayed enclosures

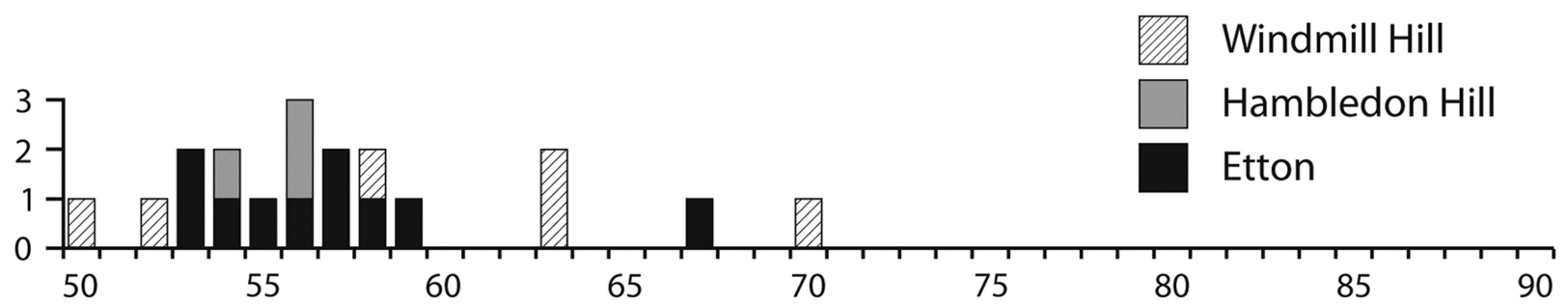

modern females
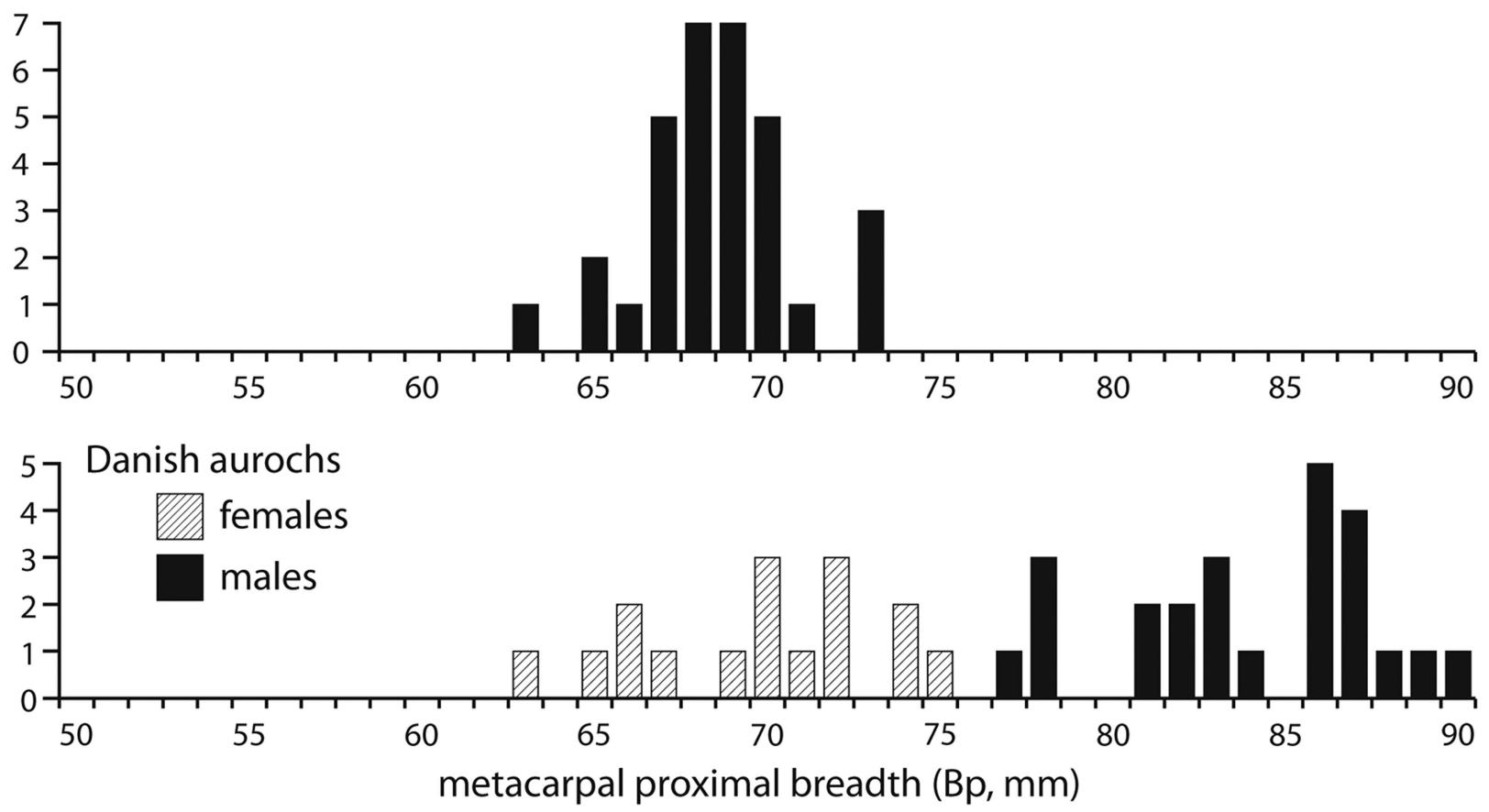

Fig. 7.

The Coneybury proximal metacarpal measurements (von den Driesch 1976; from Maltby 1990, fiche table 24), compared to those from Windmill Hill, Hambledon Hill, \& Etton (from Grigson 1999, appx 1.1; Armour-Chelu unpublished; \& Legge 2008, table 8.29, respectively), modern Danish female (from Higham 1969, supplementary table 2.3), \& prehistoric Danish aurochs of known sex (from Degerbøl \& Fredskild 1970, table 11)

Table 3 shows the obtained amplification results per DNA extract and PCR. Positive amplifications were obtained out of five samples in at least one of the aDNA extracts. In three cases it was possible to reproduce the obtained results between extractions, while specimen CM12 only produced a single amplification result out of one of the two extractions. Samples from individuals CM9, CM7, CM1, and CM10 did not produce a positive result in any of the performed amplifications. None of the six extraction blanks and the three PCR blanks per PCR round produced a positive amplification result, which allows 
K.J. Gron et al. MEETING IN THE FOREST: HUNTERS \& FARMERS AT THE CONEYBURY 'ANOMALY', WILTSHIRE

TABLE 2: MEASUREMENTS OF CATTLE BONES FROM CONEYBURY COMPARED WITH THOSE FROM OTHER BRITISH EARLY NEOLITHIC SITES

\begin{tabular}{|c|c|c|c|}
\hline Measurement & Coneybury & Other Neolithic sites & Diagnosis \\
\hline Metacarpal Bd & $56.1,53.4,57.0$ & see Figure 6 & all female \\
\hline Metacarpal Bp & $56.2,53.6,53.0,58.1,54.2,54.7,51.0$ & see Figure 7 & all female \\
\hline Metatarsal Bd & $53.5,57.1$ & $\begin{array}{l}\text { WH: } 47.5,48.2,54.6 \\
\text { Etton: } 49.2-58.9(\mathrm{~N}=10)\end{array}$ & both female \\
\hline Metatarsal Bp & 43.3 & $\begin{array}{l}\text { WH: } 40.0-48.2(\mathrm{~N}=10) \\
\text { Etton: } 43.3-51.9(\mathrm{~N}=12) \text {, aurochs } 80.5 \\
\text { HH: } 43.0-51.8(\mathrm{~N}=6)\end{array}$ & female \\
\hline Metatarsal Dp & 43.5 & $\begin{array}{l}\text { Etton: 41.2-52.9 }(\mathrm{N}=12) \\
\text { HH: 43.0-51.8 }(\mathrm{N}=6)\end{array}$ & female \\
\hline Humerus HT & 42.3 & HH: $39.0-55.2(\mathrm{~N}=57)$ & female \\
\hline Tibia Bd & 59.6 & $\begin{array}{l}\text { WH: 57.2-61.4 }(\mathrm{N}=10) \\
\text { Etton: } 55.1-62.6(\mathrm{~N}=14) \text {, outlier } 69.0\end{array}$ & female \\
\hline Calcaneus GL & 123 & $\begin{array}{l}\text { WH: } 120.9,125.1,135.8 \\
\text { Etton: } 127.4,129.1,130.4\end{array}$ & female \\
\hline Astragalus GLl & 65 & $\begin{array}{l}\text { WH: } 60-8-70.1(\mathrm{~N}=14) \text {, outlier } 80.1 \\
\text { Etton: } 63.5-69.9(\mathrm{~N}=11) \text {, aurochs } 91.2 \\
\text { HH: } 60.8-73.0(\mathrm{~N}=13)\end{array}$ & female \\
\hline
\end{tabular}

Measurements after von den Driesch (1976), from Coneybury (Maltby 1990, fiche table 24); Windmill Hill (WH) from Grigson (1999, appx 1.1); Etton from Armour-Chelu (unpublished); Hambledon Hill (HH) from Legge (2008, tables 8.27-8.32). Two clear aurochs identified at Etton are noted. The large distal tibia from Etton is most probably a domestic bull; the smallest female aurochs from Denmark measured $68 \mathrm{~mm}$ and was still in the process of fusing (Degerbøl \& Fredskild 1970, table 17). The large astragalus from Windmill Hill might be either a domestic bull or a small female aurochs

us to discard modern DNA contamination as a possible source for the obtained DNA. Moreover, the obtained sequences showed additional T-C/G-A substitutions indicative of post-mortem deamination and characteristic of endogenous ancient DNA (Gilbert et al., 2003).

Allelic dropout - a situation in which one or both chromosomal alleles are not amplified due to stochastic sampling of the DNA template due to, for example, poor DNA quality and quantity - can cause false homozygous calls (Wang et al. 2012). In the present study, this could potentially cause the misidentification of male specimens as females, so we adopted a replication strategy consisting of performing two extractions per sample and two amplifications per skeleton in order to address this potential bias.

All the five positive amplifications yielded a single $T$ in position 243 of the ZFXY gene, indicating a female sex. These are all animals of intermediate age (630 months). The perinatal specimens CM7 and CM9 did not yield any DNA, presumably due to the porosity and poor preservation of these very young calves. These could, therefore, be either male or female. Likewise specimen CM10 produced no DNA. This is unfortunate - not only is this the oldest animal present, it also has a somewhat aberrant strontium isotope ratio perhaps suggesting a different geographical origin (see below). It would have been interesting to know whether it might have been a bull - but if it was, none of its measurable limb bones has survived.

Therefore, while DNA preservation allowed sex determination in only five of the mandibles, the results underscore the zooarchaeological determination that there is no evidence of males among the cattle remains recovered from Coneybury.

\section{Conclusion}

The methods discussed above demonstrate that a group of immature and young adult female cattle, as well as some very young calves and one older individual all of unknown sex, were brought to the site and killed. The samples are small, but the female dominance and the young age at death are both exact parallels of the situation that was to appear at the causewayed enclosures in the next few centuries. The cattle were therefore managed just as intensively in the earliest Neolithic, presumably for their dairy products. 
THE PREHISTORIC SOCIETY

TABLE 3: RESULTS OF aDNA SEX DETERMINATION OF THE CONEYBURY CATTLE MANDIBLES

\begin{tabular}{|c|c|c|c|c|c|c|c|}
\hline \multirow[b]{2}{*}{ Specimen no. } & \multirow[b]{2}{*}{ Lab. no. } & \multicolumn{2}{|c|}{ Extraction 1} & \multicolumn{2}{|c|}{ Extraction 2} & \multirow[b]{2}{*}{ Consensus } & \multirow[b]{2}{*}{ Sex determination } \\
\hline & & PCR1 & PCR2 & PCR1 & PCR2 & & \\
\hline CM8 & $\mathrm{CN}-15$ & $243 \mathrm{~T}$ & No result & No result & $243 \mathrm{~T}$ & $243 \mathrm{~T}$ & female \\
\hline CM9 & $\mathrm{CN}-16$ & No result & No result & No result & No result & - & - \\
\hline CM2/CM5 & CN-18 & $243 \mathrm{~T}$ & $243 \mathrm{~T}$ & $243 \mathrm{~T}$ & $243 \mathrm{~T}$ & $243 \mathrm{~T}$ & female \\
\hline CM11 & CN-19 & No result & No result & $243 \mathrm{~T}$ & $243 \mathrm{~T}$ & $243 \mathrm{~T}$ & female \\
\hline CM6 & CN-21 & $243 \mathrm{~T}$ & No result & $243 \mathrm{~T}$ & $243 \mathrm{C} / \mathrm{T}$ ?* & $243 \mathrm{~T}$ & female \\
\hline CM12 & $\mathrm{CN}-22$ & No result & $243 \mathrm{~T}$ & No result & No result & 243T? & female? \\
\hline CM7 & $\mathrm{CN}-23$ & No result & No result & No result & No result & - & - \\
\hline CM1 & $\mathrm{CN}-24$ & No result & No result & No result & No result & - & - \\
\hline CM10 & $\mathrm{CN}-25$ & No result & No result & No result & No result & - & - \\
\hline
\end{tabular}

Starred result indicates a sequence with high background noise

\section{ISOTOPIC ANALYSES OF THE CATTLE \& ROE DEER}

We have conducted analyses of carbon, nitrogen, oxygen, strontium, and sulphur isotopes from bones and teeth. Separately, and in combination, these can address diet, past feeding environments, husbandry, birth seasonality, and mobility. Such multiple-method studies have been rare in the past, as most studies use fewer, or just one, analytical approach (eg Drucker et al. 2003; Noe-Nygaard et al. 2005; Balasse and Tresset 2007; Towers et al. 2014; Price et al. 2015; Gron et al. 2015; 2016; Britton 2017; Gerling et al. 2017; Balasse et al. 2017).

\section{Sample selection}

The remains of multiple domestic cattle (Bos taurus) and roe deer (Capreolus capreolus) were selected for isotopic analysis. Other species were recovered from Coneybury, but were very few in number (Maltby 1990). Any data obtained would be purely anecdotal, and would not justify the destructive methods.

Different cattle were selected using a Minimum Number of Individuals (MNI)-based approach (Casteel \& Grayson 1977). This was based on side, biometry, gross differences in overall size, ontogeny, and life processes such as dental attrition. As a result it can be demonstrated that each skeletal element sampled derives from a different entity (see Appendix S1 for a detailed MNI justification). Given the limited material, two skeletal elements were sampled for each species: for domestic cattle, mandibles $(\mathrm{MNI}=8)$ and metacarpals $(\mathrm{MNI}=5)$; and for roe deer, mandibles $(\mathrm{MNI}=4)$ and radii $(\mathrm{MNI}=6)$. These numbers are fewer than the published MNI values, because a limited amount of the material was unavailable for analysis on account of being on public display. In addition, several further samples were selected which may or may not derive from additional animals. These bring the total numbers of mandibles and metacarpals from domestic cattle to $\mathrm{N}=10$ and $\mathrm{N}=7$, respectively; and mandibles and radii of roe deer to $\mathrm{N}=4$ and $\mathrm{N}=7$ respectively. In some cases the mandibles and postcranial elements may derive from the same animal.

The reasons for this sampling strategy were twofold. First, it may mitigate issues resulting from potential diagenetic results and/or poor collagen preservation because it permits the largest possible sample from different animals to be obtained in the event of extraction or analysis failure in some of the samples. Secondly, we have analysed bone collagen and tooth enamel carbonate from the same mandible, so it is useful in ensuring that there is no systematic offset between mandibular (which can be securely paired with tooth data) and postcranial bone.

The vast majority of the faunal material sampled derives from the primary deposit Context 2538 (Table S2). There are, however, five specimens from other contexts. Specimen R5, a roe deer, is from primary Context 2517, and is therefore associated with the deposition. Two cattle mandibles (CM10 \& CM12) and two metacarpals (MC1 \& MC7) were recovered from Contexts 2237 and 2513, and 2302 and 2231 respectively. At least some of the bone material from the colluvial deposits is part of the primary deposition (Maltby 1990). We therefore include these few specimens in our study, but acknowledge the possibility that they may not be contemporaneous with the other materials. Regardless, these samples show no notable divergence from the main dataset, and their inclusion or removal does not affect interpretations. Specific elements sampled are listed in Table 1 and specific 
K.J. Gron et al. MEETING IN THE FOREST: HUNTERS \& FARMERS AT THE CONEYBURY 'ANOMALY', WILTSHIRE

provenance and methods are detailed in Table S2 and Appendix S1 respectively.

\section{Roe deer as an interpretative baseline}

As noted above, Coneybury's earliest Neolithic faunal assemblage is unique in having an appreciable number of wild animal remains, primarily roe deer. For isotope investigations, this is a major advantage, because wild species offer an internal baseline against which to compare the cattle. Differences in diet and mobility between roe deer and cattle are likely to result from the human manipulation of the domesticated livestock.

In order to use deer as an interpretive baseline, we make several assumptions. First, we assume that the deer dietary isotopes reflect the range of available habitats. Roe deer show remarkable flexibility in their use of natural and anthropogenic habitats, and this is reflected in their carbon and nitrogen isotope ratios (Gron \& Rowley-Conwy 2017). But despite this flexibility roe deer can still best be described as a woodland species that will, at least in part, gravitate towards any available forests (Morellet et al. 2011). If forested areas were present, we would expect the deer to be feeding in them.

\section{CATTLE BIRTH SEASON: CARBON \& OXYGEN ISOTOPES IN TOOTH ENAMEL}

The enamel of a tooth forms over a period of time, mineralisation starting at the cusp and ending at the enamel-root junction (ERJ). Enamel captures the oxygen isotope values of ingested water as it mineralises. Because enamel is not generally altered after this occurs, the isotope values remain fixed (Sullivan \& Krueger 1981). Differences between summer and winter ingested water isotope values, when sampled in sequence down a cow's tooth, take the form of sinusoidal curves. Multiple samples taken down a tooth also reveal changes in the animal's diet over the period when the tooth formed as carbon isotope values of the animal's diet are also incorporated (Balasse et al. 2012). Relative to each-other, and because the M1, $\mathrm{M} 2$, and M3 form in that sequence, these teeth may preserve a quite lengthy dietary and seasonal history (eg Gron et al. 2015).

We obtained 203 tooth enamel carbon $\left(\delta^{13} \mathrm{C}\right)$ and oxygen $\left(\delta^{18} \mathrm{O}\right)$ isotope measurements from nine teeth (Table S3; methods in Appendix S1). Reported $\delta^{18} \mathrm{O}$ values were converted to values relative to Vienna Standard Mean Ocean Water (VSMOW) using the equation $\delta^{18} \mathrm{O}_{\text {vSMOW }}=1.03091 \times \delta^{18} \mathrm{O} \mathrm{PDB}+30.91$ given in Sharp (2007). The 1st, 2nd, and 3rd molar profiles all show the sinusoidal variation in $\delta^{18} \mathrm{O}$ characteristic of seasonal variation in ingested water (Fricke et al. 1998).

The first molar $\delta^{13} \mathrm{C}$ profiles (Fig. 8, bottom) show a rise characteristic of the onset of rumination after the birth of the animal (Towers et al. 2014). Two animals, represented by OCM3 and OCM6, show a slight dip in these values before climbing, which illustrates the sequence of in utero rumination (through the mother's digestion); parturition; and the onset of rumination (Towers et al. 2014). One animal, OCM10, appears to have started ruminating somewhat later than the other cattle and may have suckled longer. Based on the characteristic rise and close similarity with the other teeth, the loose molar OCM3 is hereby identified as an M1.

Second and 3rd molar $\delta^{13} \mathrm{C}$ profiles (Fig. 9, bottom, Fig. 10, bottom) all vary within $1.5 \%$ over the annual cycle, indicating little variation in the environments from which the diet was obtained over the course of the year.

Unfortunately there are only two mandibles that contain both M2 and M3. Modelling birth season (eg Balasse et al. 2012) on this few animals could therefore be misleading. We therefore focus on the M1s, which derive from five individuals. The use of Method 2 estimate of birth seasonality of Towers et al. (2014) from M1 tooth enamel requires unambiguous oxygen maxima $\left(\delta^{18} \mathrm{O}_{\max }\right)$ and minima $\left(\delta^{18} \mathrm{O}_{\min }\right)$ from each individual tooth. Unfortunately, this is the case for only two M1s: OCM1 and OCM6 (Fig. 10, top). For the other three teeth, OCM2, OCM3, and OCM10, there is some ambiguity because their $\delta^{18} \mathrm{O}$ values are trending either up or down at the highest or lowermost sample. Nonetheless, these five molars are the best opportunity for understanding seasonality of birth at Coneybury, so a compromise was made. Method 2 estimates of birth seasonality were calculated for all five molars, using simply the absolute highest and lowest $\delta^{18} \mathrm{O}$ values, regardless of whether they represent the actual summer maximum or winter minimum. However, any conclusions drawn from these data should be considered qualified; only the data from OCM1 and OCM6 clearly represent the duration of the cattle birth season. 
THE PREHISTORIC SOCIETY

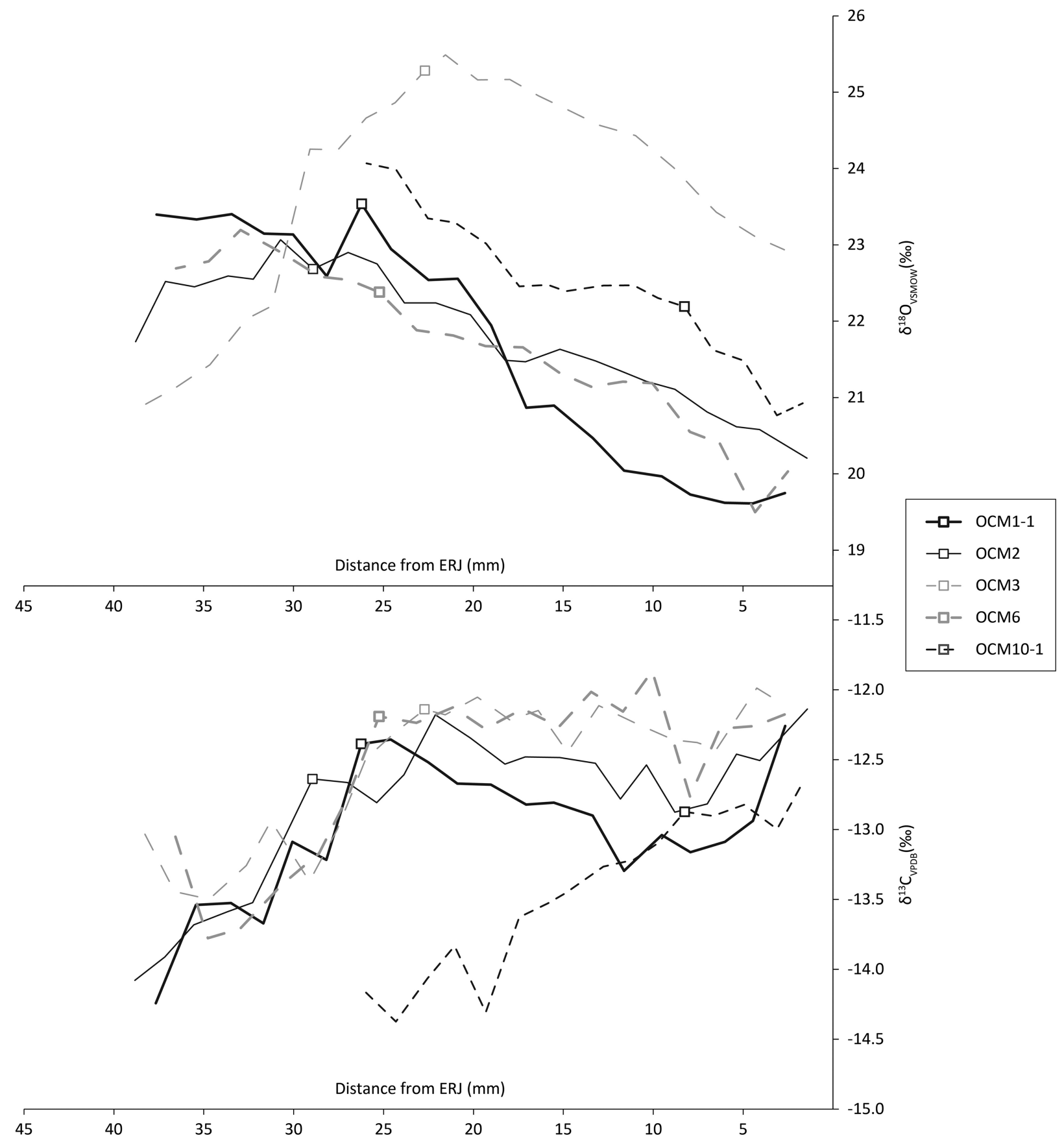

Fig. 8 .

First molar tooth enamel sequential carbonate isotope data. Boxes indicate $\delta^{18} \mathrm{O}_{\mathrm{CG}}$ and $\delta^{13} \mathrm{C}_{\mathrm{CG}}$ 
K.J. Gron et al. MEETING IN THE FOREST: HUNTERS \& FARMERS AT THE CONEYBURY 'ANOMALY', WILTSHIRE

To calculate birth season duration, Towers et al. (2014) use the change in gradient representing the onset of rumination in $\delta^{13} \mathrm{C}$ values $\left(\delta^{13} \mathrm{C}_{\mathrm{CG}}\right)$ and their associated $\delta^{18} \mathrm{O}$ values $\left(\delta^{18} \mathrm{O}_{\mathrm{CG}}\right)$ using the equation $\left[\left[\delta^{18} \mathrm{O}_{\mathrm{CG}}-\delta^{18} \mathrm{O}_{\min }\right]=0.5 \Delta\left[\cos \left(\mathrm{A}_{\mathrm{CG}}\right)+1\right]\right]$ where $\Delta=$ $\delta^{18} \mathrm{O}_{\max }-\delta^{18} \mathrm{O}_{\min }$ (see Towers et al. 2014). Associated values for calculation of the angle of the change in gradient $\left(\mathrm{A}_{\mathrm{CG}}\right)$ are listed in Table 4 , and are indicated by boxes on the oxygen and carbon plots in Fig. 10. If all animals are considered, then the spread of births is $(98.0 / 360) \times 12=3.27$ months. If only OCM1 and OCM6 are considered, then the spread of births is over $(55.9 / 360) \times 12=1.86$ months. However, since the sulphur isotope data show that the cattle came from various different places (see below), the fact that maxima and minima are in most cases estimates, the qualitative assignment of $\delta^{13} \mathrm{C}_{\mathrm{CG}}$, and in consideration of the associated error implicit in this method (Towers et al. 2014), these should be considered rough estimates at best.

Therefore, $\delta^{13} \mathrm{C}$ and $\delta^{18} \mathrm{O}$ data provide evidence of one birthing season, probably in the spring. A conservative estimate based only on two individuals is just below 2 months in duration. A more speculative estimate, based on five individuals, is a little over 3 months. These spans may be slightly longer than we would expect, but we see no evidence for specific manipulation for multi-season birthing of the kind shown to have taken place in the Early Neolithic of southern Scandinavia (Gron et al. 2015).

\section{CATTLE \& ROE DEER MOVEMENT \& DIETARY NICHE}

\section{Isotopes and landscapes}

Understanding the geographic origins of the cattle and deer and the landscapes in which they lived is fundamental for our understanding of the Event. Previous studies in animals have shown that strontium isotope values in tooth enamel relate to geographical origins (Price et al. 2015; Gron et al. 2016), while carbon and nitrogen in bone record diet (Drucker et al. 2003; Noe-Nygaard et al. 2005; Gerling et al. 2017). Sulphur analyses of bone collagen have so far largely aimed at understanding diet and coastal proximity (Nehlich 2015) but, in herbivores, such analyses may also indicate variation in geographical origin (Towers et al. 2011), even on marine carbonate rocks such as chalk (Jay et al. 2013).

The various isotope systems are derived from different tissues. As discussed above, we sampled

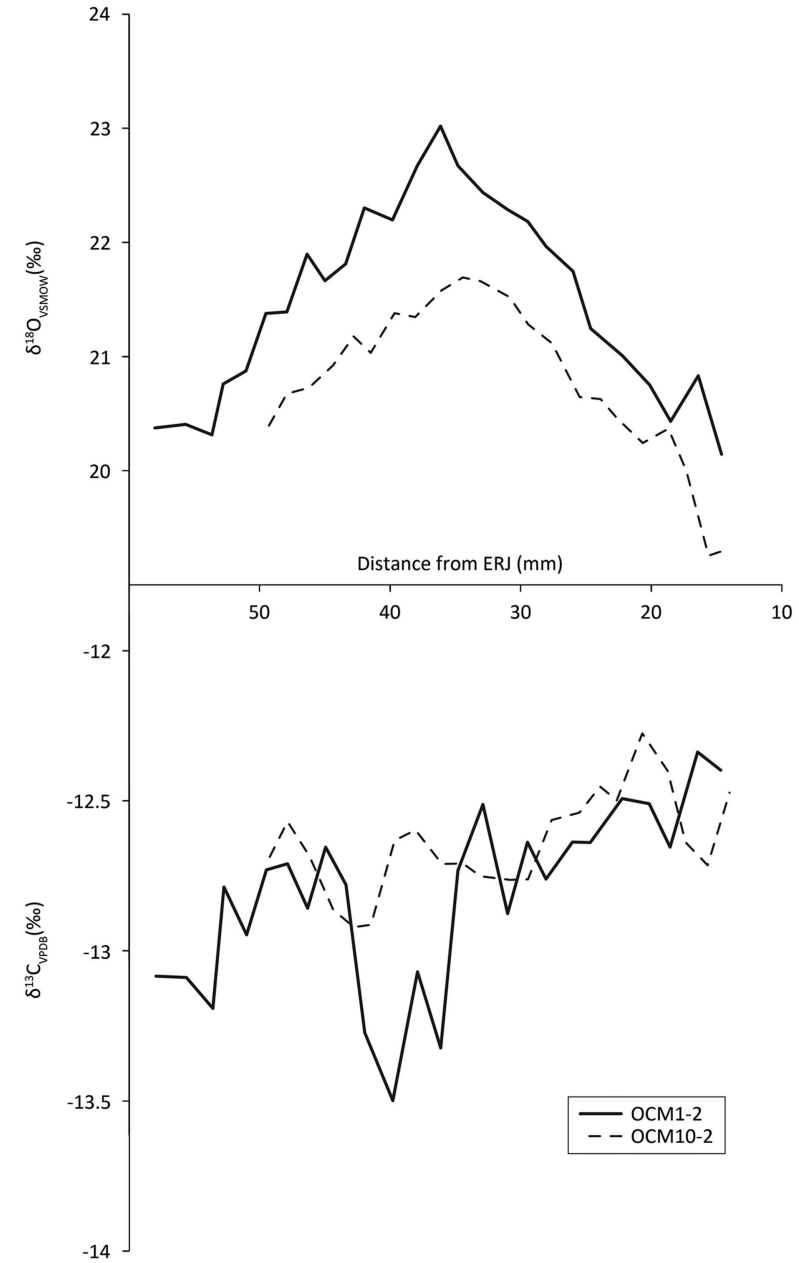

Fig. 9.

Second molar tooth enamel sequential carbonate isotope profiles

mandibles (both species), metacarpals (cattle only), and radii (roe deer only). For the mandibles, strontium was sampled from the enamel of individual teeth, each of which records a discrete period of less than 1 year in the animal's life when the mineralisation is completed. Sulphur, carbon and nitrogen were sampled from mandibular and postcranial bone collagen, which constantly remodels, so these values are thus averaged over several years. The cattle teeth sampled for strontium represent different stages of enamel formation and maturation (Brown et al. 1960), and where possible multiple teeth were sampled from the same individual.

Bone collagen carbon, nitrogen and sulphur isotope ratios were obtained from 28 samples (Table S4, summarised in Table 5, graphically in Fig. 11). All 


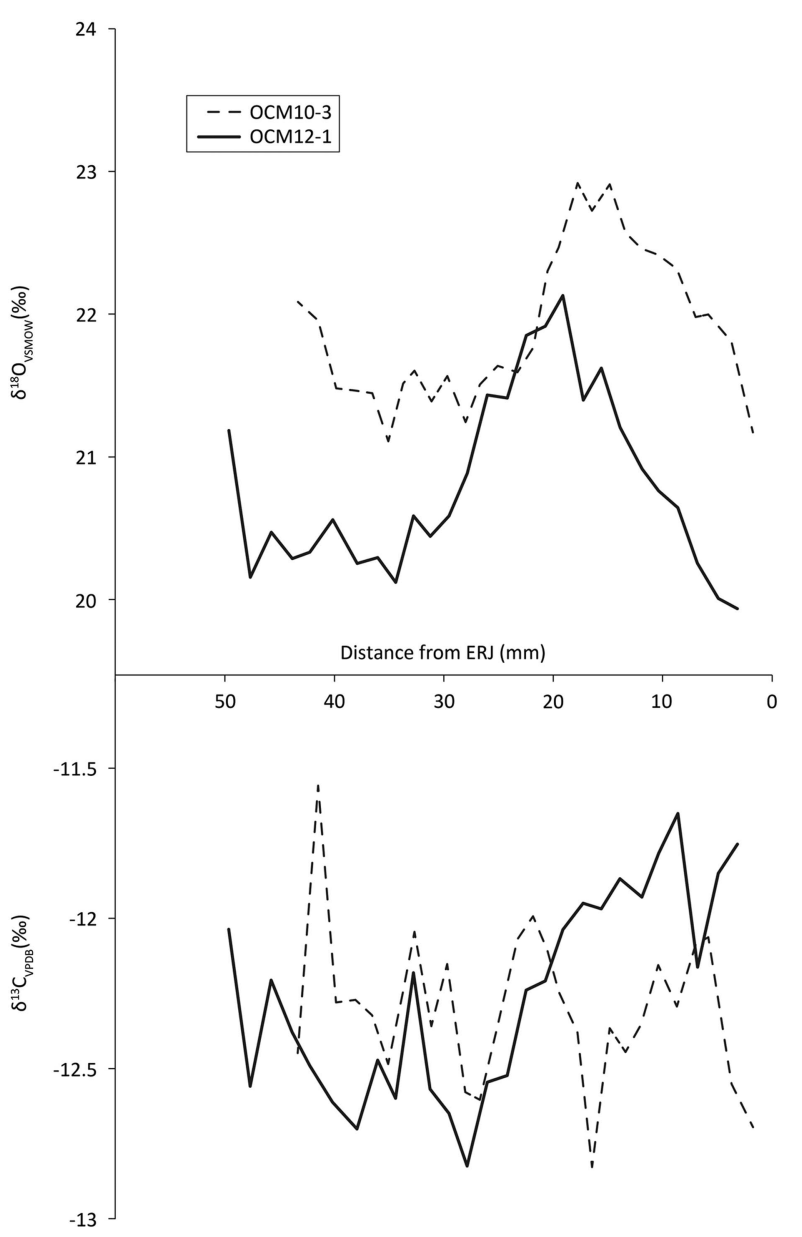

Fig. 10.

Third molar tooth enamel sequential carbonate isotope profiles

values fall within the acceptable atomic C:N range (2.9-3.6) (DeNiro 1985) and therefore show a low probability of diagenesis, with one exception, the roe deer radius specimen R6. Similarly, all data yielded atomic C:S and atomic N:S ratios that meet established criteria for quality control (Nehlich \& Richards 2009) with the single exception of cow mandible specimen CM4 which yielded an atomic C:S ratio outside the acceptable range. We have therefore excluded data deriving from these two specimens from further consideration and interpretation.

There is no systematic difference in the carbon ( $\mathrm{T}$ test: $\mathrm{t}(14)=1.1, \mathrm{p}=0.29)$, nitrogen $(\mathrm{t}(14)=0.31$, $\mathrm{p}=0.76)$, or sulphur isotope ratios $(\mathrm{t}(14)=0.49$, $\mathrm{p}=0.63$ ) between the cattle mandibles and metacarpals. Similarly, there is no systematic offset in carbon $(\mathfrak{t}(8)=0.21, \mathrm{p}=0.84)$, or nitrogen $(\mathrm{t}(8)=0.16$,
TABLE 4: CALCULATED PARAMETERS FOR DETERMINATION OF METHOD 2 BIRTH SEASON (TOWERS ET AL. 2014)

\begin{tabular}{|c|c|c|c|c|c|}
\hline & $\begin{array}{c}\text { OCM1- } \\
1\end{array}$ & OCM2 & OCM3 & OCMG & $\begin{array}{c}\text { OCM10 } \\
1\end{array}$ \\
\hline$\delta^{18} \mathrm{O}_{\max }(\% o)$ & 23.5 & 23.1 & 25.5 & 23.2 & 24.1 \\
\hline$\delta^{13} \mathrm{C}_{\mathrm{CG}}(\% \circ)$ & -12.4 & -12.6 & -12.1 & -12.2 & -12.9 \\
\hline$\delta^{18} \mathrm{O}_{\mathrm{CG}}(\% o)$ & 23.5 & 22.7 & 25.8 & 22.4 & 22.2 \\
\hline $\begin{array}{l}\delta^{18} \mathrm{O}_{\mathrm{CG}^{-}} \\
\delta^{18} \mathrm{O}_{\min }(\% o)\end{array}$ & 3.9 & 2.5 & 4.4 & 2.9 & 1.4 \\
\hline$\delta^{18} \mathrm{O}_{\min }(\% o)$ & 19.6 & 20.2 & 20.9 & 19.5 & 20.8 \\
\hline $\begin{array}{c}\delta^{18} \mathrm{O}_{\max } \\
\delta^{18} \mathrm{O}_{\min }(\% o)\end{array}$ & 3.9 & 2.9 & 4.6 & 3.7 & 3.3 \\
\hline$A_{C G}\left({ }^{\circ}\right)$ & 0 & 43.3 & 24.7 & 55.9 & 98.0 \\
\hline
\end{tabular}

$\delta^{18} \mathrm{O}$ is versus Vienna Standard Mean Ocean Water (VSMOW)

$\mathrm{p}=0.88$ ) isotope ratios between the roe radii and mandibles. There is a nearly significant offset in roe deer sulphur isotope ratios $(t(8)=2.28, p=0.052)$ between the radii and mandibles, but the sample size is small and there is a lack of difference in the other ratios. It is possible that the mandibles and the radii come from different deer and thus reflect interindividual difference. All collagen data will therefore be treated in aggregate.

In the most general terms, deer show higher variance in carbon and nitrogen isotope ratios than do the cattle (Table 5). There are no significant differences between summed cattle and deer $\delta^{15} \mathrm{~N}$ values $(\mathrm{t}(24)=$ $0.90, p=0.38$ ) although the cattle have higher, and significantly different $\delta^{13} \mathrm{C}$ values than deer $(\mathrm{t}(24)=$ 4.97, $\mathrm{p}<0.01$ ), all of which are greater than $\delta^{13} \mathrm{C}$ of c. $-22.5 \%$. The $\delta^{34} S$ values for the cattle $\left(\sigma^{2}=2.56\right)$ are more variable than for the deer $\left(\sigma^{2}=0.49\right)$ with a larger range, and are significantly different $(\mathrm{t}(24)=$ $3.9, \mathrm{p}<0.01)$.

\section{Strontium and long-distance movements}

Nineteen strontium isotope ratios $\left({ }^{87} \mathrm{Sr} /{ }^{86} \mathrm{Sr}\right)$ were obtained from enamel, 15 from cattle and four from roe deer (Fig. 12; Table 6). Cattle ${ }^{87} \mathrm{Sr} /{ }^{86} \mathrm{Sr}$ values ranged between 0.7078 and 0.7088 , roe deer between 0.7077 and 0.7079 (Table 4). In general, all samples have very similar values that fall within the possible range of the Cretaceous Chalk biosphere, ie from chalk at $\sim 0.7075$, Quaternary drift at $\sim 0.7087$, to rainwater at 0.7092 (Montgomery et al. 2000; Evans et al. 2010; Warham 2012). Viner et al. (2010) give a local range of around $0.7078-0.7090$ for the site of 
K.J. Gron et al. MEETING IN THE FOREST: HUNTERS \& FARMERS AT THE CONEYBURY 'ANOMALY', WILTSHIRE

TABLE 5: SUMMARY BONE COLLAGEN CARBON, NITROGEN, AND SULPHUR DATA

\begin{tabular}{|c|c|c|c|c|c|c|}
\hline & & Average (\%o) & Minimum (\%o) & Maximum (\%o) & Range (\%o) & Std dev. \\
\hline \multicolumn{7}{|l|}{ Carbon $\left(\delta^{13} C\right)$} \\
\hline Cattle mandible & $\mathrm{N}=9$ & -22.4 & -22.7 & -21.9 & 0.8 & 0.3 \\
\hline Cattle metacarpal & $\mathrm{N}=7$ & -22.2 & -22.7 & -21.4 & 1.2 & 0.4 \\
\hline Overall cattle & $\mathrm{N}=16$ & -22.3 & -22.7 & -21.4 & 1.2 & 0.4 \\
\hline Roe deer mandible & $\mathrm{N}=4$ & -23.5 & -25.2 & -22.0 & 3.2 & 1.3 \\
\hline Roe deer radius & $\mathrm{N}=6$ & -23.7 & -24.7 & -22.3 & 2.4 & 0.8 \\
\hline Overall roe deer & $\mathrm{N}=10$ & -23.6 & -25.2 & -22.0 & 3.2 & 1.0 \\
\hline \multicolumn{7}{|l|}{ Nitrogen $\left(\delta^{15} N\right)$} \\
\hline Cattle mandible & $\mathrm{N}=9$ & 4.0 & 3.2 & 4.7 & 1.4 & 0.4 \\
\hline Cattle metacarpal & $\mathrm{N}=7$ & 4.0 & 3.5 & 5.0 & 1.6 & 0.6 \\
\hline Overall cattle & $N=16$ & 4.0 & 3.2 & 5.0 & 1.8 & 0.5 \\
\hline Roe deer mandible & $\mathrm{N}=4$ & 3.7 & 3.1 & 5.2 & 2.1 & 1.0 \\
\hline Roe deer radius & $\mathrm{N}=6$ & 3.8 & 2.7 & 4.7 & 1.9 & 0.7 \\
\hline Overall roe deer & $\mathrm{N}=10$ & 3.8 & 2.7 & 5.2 & 2.5 & 0.8 \\
\hline \multicolumn{7}{|l|}{ Sulphur $\left(\delta^{34} S\right)$} \\
\hline Cattle mandible & $N=9$ & 11.4 & 9.3 & 13.3 & 4.0 & 1.3 \\
\hline Cattle metacarpal & $\mathrm{N}=7$ & 11.8 & 8.7 & 14.8 & 6.2 & 2.0 \\
\hline Overall cattle & $\mathrm{N}=16$ & 11.6 & 8.7 & 14.8 & 6.2 & 1.6 \\
\hline Roe deer mandible & $\mathrm{N}=4$ & 14.1 & 13.6 & 14.5 & 0.9 & 0.4 \\
\hline Roe deer radius & $\mathrm{N}=6$ & 13.4 & 12.5 & 14.2 & 1.7 & 0.6 \\
\hline Overall roe deer & $\mathrm{N}=10$ & 13.7 & 12.5 & 14.5 & 2.0 & 0.7 \\
\hline
\end{tabular}

Specimens CM4 \& R6 dropped due to unacceptable atomic elemental ratios

Durrington Walls, less than $5 \mathrm{~km}$ from Coneybury in the same Cretaceous Chalk landscape. Neolithic-Iron Age humans excavated from the chalk of southern Britain and the Yorkshire Wolds have ${ }^{87} \mathrm{Sr} /{ }^{86} \mathrm{Sr}$ values ranging upwards from 0.7077 (Montgomery et al. 2000; Jay et al. 2013; Montgomery et al. forthcoming). These studies indicate that all the Coneybury individuals can be considered local. A single exception, while still within the chalk biosphere range, is specimen CM10 - the oldest animal from Coneybury, whose sex could not be resolved by aDNA analysis (see above). Samples from this animal's M1, M2, and M3 show a progressive increase (Fig. 9); since the teeth mineralise in this order, the animal appears to have been moving further away from Coneybury during its lifetime, although it returned before it was slaughtered.

This raises the question of the distances implied by 'local' strontium isotope values. Strontium isotope ratios reflect the bedrock geology, which in Wiltshire at Coneybury is Cretaceous Chalk with no overlying drift and plants here have ${ }^{87} \mathrm{Sr} /{ }^{86} \mathrm{Sr}$ of $0.7078-0.7079$ (Evans et al. 2010). To the west and east of Coneybury, the Chalk is covered with Quaternary alluvium and river terrace sands and gravels which, near Bulford and Durrington, provide higher values of 0.7084-0.7087 (Evans et al. 2010), but which are still within the maximum chalk biosphere range of $0.7075-0.7092$. One must travel at least $20 \mathrm{~km}$ in order to reach areas with different biosphere strontium isotope ratios above 0.7092 (Evans et al. 2010) and, in some directions, substantially larger distances. Both the cattle and the roe deer are thus consistent with the local strontium isotope biosphere so they likely lived no farther than $20 \mathrm{~km}$ from Coneybury and the observed variation may derive from moving cattle locally between upland regions devoid of drift and lowland regions with drift deposits.

\section{Sulphur and short-distance movements}

In contrast to the strontium isotope values, there is variation in the animals' sulphur isotope ratios. The roe deer $\delta^{34} S$ values vary by only $2.0 \%$ while the cattle vary by as much as $6.2 \%$. But is this variance due to a combination of the age of the animals and movement from place to place, the adults perhaps moving several times but the newborn animals not doing so? Or does it signal differences in geographic origin? The age-at-death data allow an assessment of these hypotheses (Table 7). Two cattle aged 615 months have $\delta^{34} S$ values that diverge by $3.7 \%$ o while four animals of different ontogenetic ages (CM7, CM9, CM1, and CM12) all have very similar $\delta^{34} \mathrm{~S}$ 
THE PREHISTORIC SOCIETY
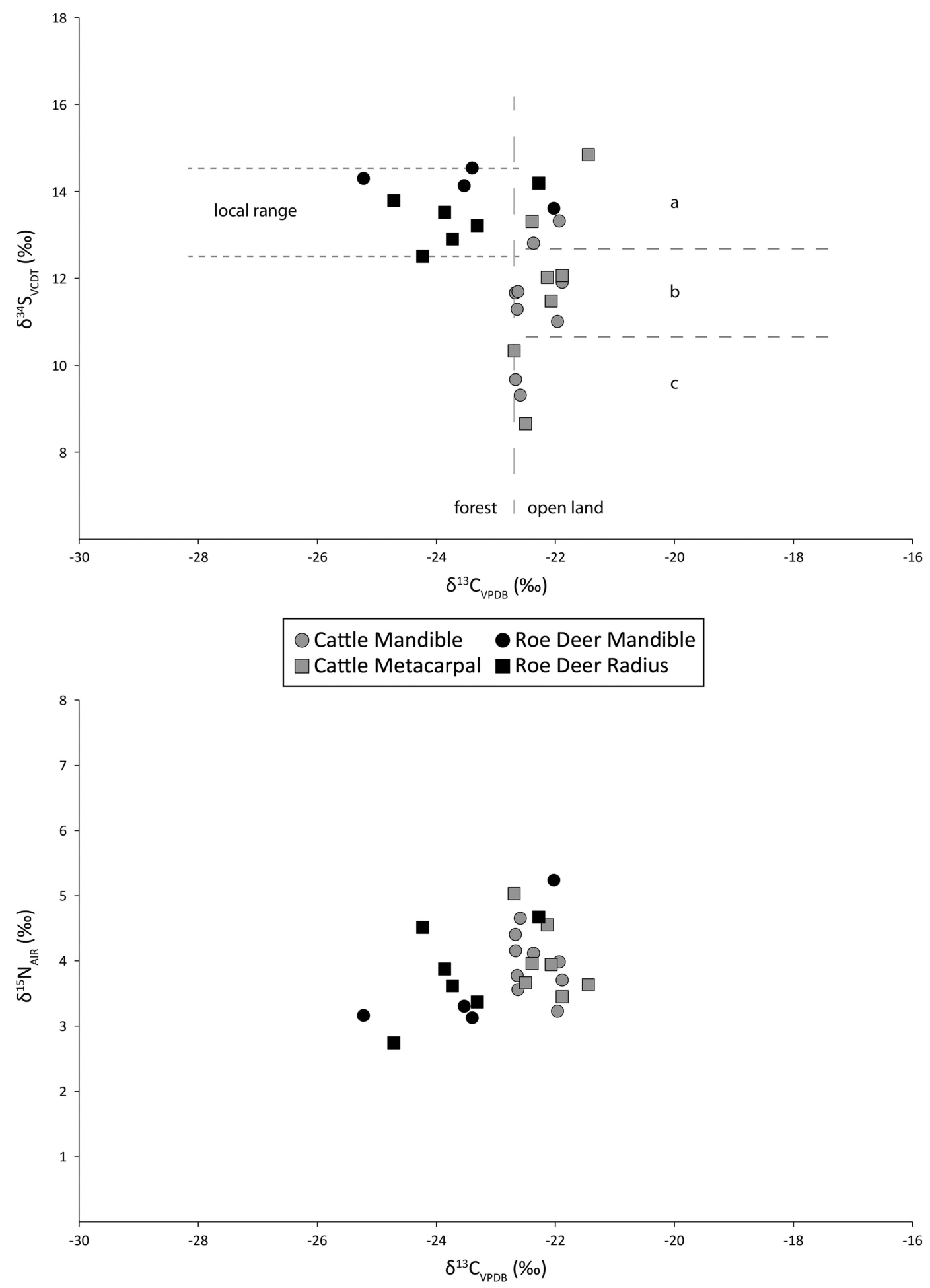

Fig.11.

Carbon, nitrogen, and sulphur isotope data 
K.J. Gron et al. MEETING IN THE FOREST: HUNTERS \& FARMERS AT THE CONEYBURY 'ANOMALY', WILTSHIRE

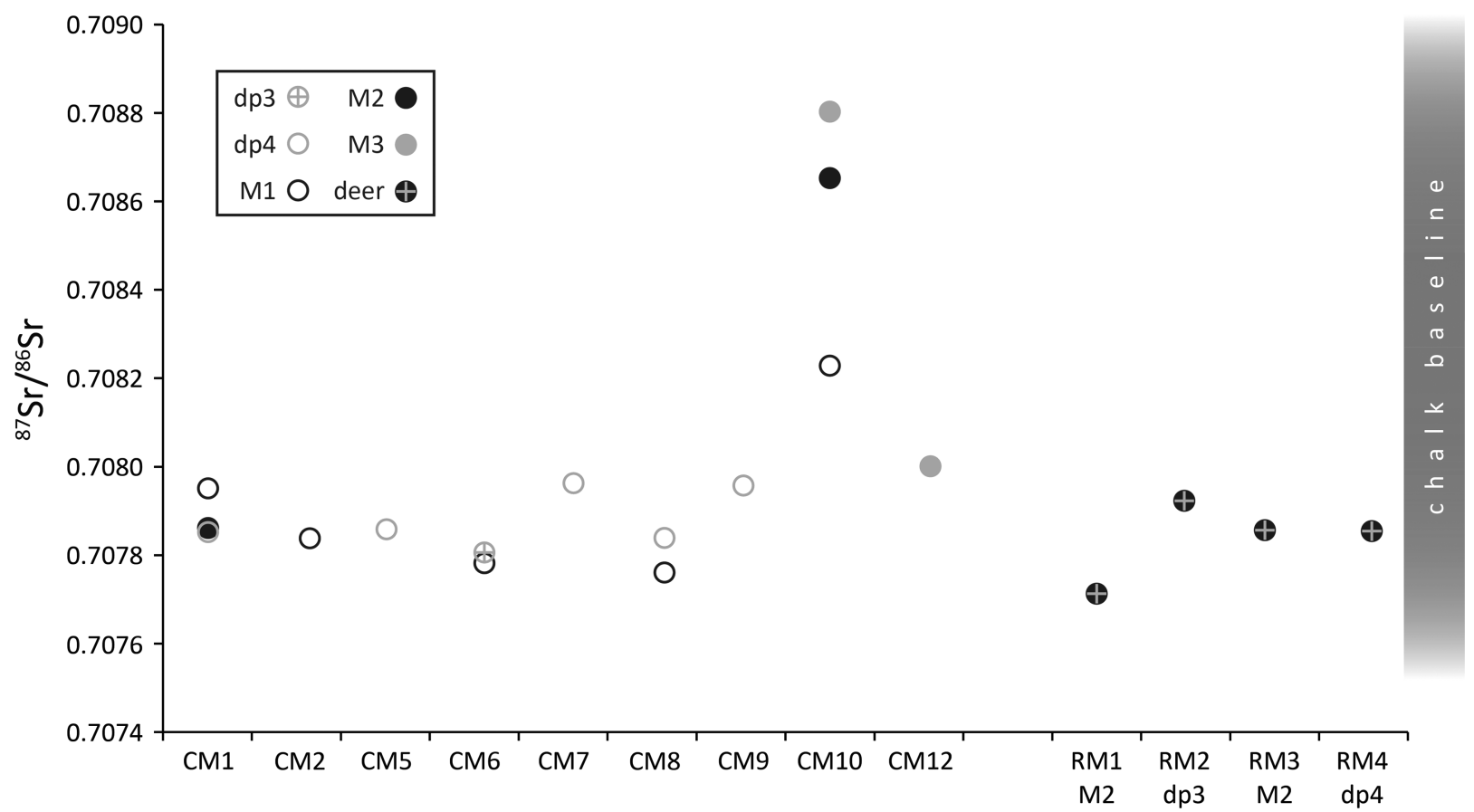

Fig. 12.

Tooth enamel ${ }^{87} \mathrm{Sr} /{ }^{86} \mathrm{Sr}$ values. Chalk baseline from Montgomery et al. (2000), Evans et al. (2010), \& Warham 2012

values (range 0.9\%o). Therefore, the most likely explanation is different geographic origins.

We assume that the roe deer were killed locally, as the deer appear to have been brought to the site whole and butchered on the spot, rather than being introduced as separate elements (Maltby 1990). It is true that roe deer are not large animals, usually under $25 \mathrm{~kg}$ (Fruziński et al. 1982), so a complete carcass could be carried over an appreciable distance. However, skeletal part representation of the much larger red deer (Cervus elaphus) was similar, and included elements of the axial skeleton (Maltby 1990), so both species were very likely killed nearby.

On the basis of this assumption, local deer bone collagen sulphur value variation is $2.0 \%$, with an average of $13.6 \%$. This value is characteristic of coastal environments affected by sulphate aerosols from sea spray (Nehlich 2015). Coneybury is $c .50 \mathrm{~km}$ inland, such that these values are probably best explained by the underlying marine chalk sediment on which the site rests. These can result in similar values (Jay et al. 2013). Given that $\delta^{13} \mathrm{C}$ and $\delta^{15} \mathrm{~N}$ values approximate the range of roe deer dietary variation in locally available feeding environments, the range of variation in the sulphur isotope data can also be taken as what one would expect to see in different deer at the same location. The same is true for the limited number of four roe deer tooth enamel strontium isotope values, which have a relatively insignificant ${ }^{87} \mathrm{Sr} /{ }^{86} \mathrm{Sr}$ range of 0.00021 , much less than the range of variation of 0.00062 seen for the feral herd of Chillingham cattle that are restricted to the Chillingham estate in Northumberland (Towers et al. 2017).

If we accept that the range of variation in the roe deer sulphur isotope ratios is what is expected in animals living in a single locality, then the cattle, with over three times the variation in their sulphur isotope ratios, come from at least three different places. However, this is a minimum estimate within the resolution of the technique and it is not impossible that, while not distinguishable isotopically, each animal came from a different place. The three notional groups are indicated in Figure 11. One of the cattle specimens indeed falls some way above the top of group a, and may mean that there was a fourth group represented by just one animal. Roe deer $\delta^{34} S$ values are similar to one of the cattle groups, but they were feeding in a different environment (see below), so they may add yet another area of origin. 
TABLE 6: STRONTIUM ISOTOPE SAMPLING INFORMATION AND DATA

\begin{tabular}{|c|c|c|c|c|c|c|c|c|c|}
\hline $\begin{array}{l}\text { Specimen } \\
\text { no. }\end{array}$ & Sample no. & $\begin{array}{c}\text { Earth sciences } \\
\text { sample no. }\end{array}$ & Species & $\begin{array}{c}\text { Element } \\
\text { (mandibular) }\end{array}$ & Side & Side \& lobe & $\begin{array}{c}\text { Distance from ERJ } \\
(\mathrm{mm})\end{array}$ & ${ }^{87} \mathrm{Sr} /{ }^{86} \mathrm{Sr}$ & $2 S E$ \\
\hline CM1 & CM1Sr-8 & A135-1 & Bos taurus & $\mathrm{dp} 4$ & $\mathrm{R}$ & buccal, distal lobe & 7.94 & 0.707852 & 0.000008 \\
\hline CM1 & CM1Sr-9 & A135-6 & Bos taurus & M1 & $\mathrm{R}$ & buccal, mesial lobe & 4.91 & 0.707952 & 0.000010 \\
\hline CM1 & CM1Sr-10 & A135-13 & Bos taurus & $\mathrm{M} 2$ & $\mathrm{R}$ & buccal, mesial lobe & 11.5 & 0.707862 & 0.000011 \\
\hline $\mathrm{CM} 2$ & CM2Sr-7 & A135-3 & Bos taurus & M1 & $\mathrm{R}$ & buccal, distal lobe & 2.98 & 0.707838 & 0.000009 \\
\hline CM5 & CM5Sr-4 & A135-10 & Bos taurus & $\mathrm{dp} 4$ & $\mathrm{R}$ & buccal, distal lobe & 11.34 & 0.707858 & 0.000010 \\
\hline CM6 & CM6Sr-2 & A135-9 & Bos taurus & M1 & $\mathrm{L}$ & buccal, mesial lobe & 3.44 & 0.707782 & 0.000011 \\
\hline CM6 & CM6Sr-1 & A135-19 & Bos taurus & $\mathrm{dp} 3$ & $\mathrm{~L}$ & buccal, anterior part & 2.03 & 0.707806 & 0.000008 \\
\hline CM7 & $\mathrm{CM} 7 \mathrm{Sr}-3$ & A135-4 & Bos taurus & $\mathrm{dp} 4$ & $\mathrm{~L}$ & buccal, distal lobe & 16.84 & 0.707963 & 0.000009 \\
\hline CM8 & CM8Sr-5 & A135-5 & Bos taurus & $\mathrm{dp} 4$ & $\mathrm{R}$ & buccal, distal lobe & near crown & 0.707839 & 0.000010 \\
\hline CM8 & CM8Sr-6 & A135-12 & Bos taurus & M1 & $\mathrm{R}$ & buccal, distal lobe & 24.05 & 0.707761 & 0.000011 \\
\hline CM9 & CM9Sr-11 & A135-2 & Bos taurus & $\mathrm{dp} 4$ & $\mathrm{~L}$ & $\begin{array}{l}\text { bucca, mesial and } \\
\text { intermediate lobe }\end{array}$ & near crown & 0.707958 & 0.000008 \\
\hline CM10 & CM10Sr-18 & A135-14 & Bos taurus & M2 & $\mathrm{L}$ & buccal, mesial lobe & 4.28 & 0.708652 & 0.000008 \\
\hline CM10 & CM10Sr-17 & A135-15 & Bos taurus & M1 & $\mathrm{L}$ & buccal, mesial lobe & 2.31 & 0.708228 & 0.000007 \\
\hline CM10 & CM10Sr-19 & A135-16 & Bos taurus & M3 & $\mathrm{L}$ & buccal, mesial lobe & 3.54 & 0.708803 & 0.000009 \\
\hline CM12 & CM12Sr-16 & A135-18 & Bos taurus & M3 & $\mathrm{R}$ & buccal, mesial lobe & 8.17 & 0.708001 & 0.000014 \\
\hline RM1 & RM1Sr-14 & A135-8 & $\begin{array}{l}\text { Capreolus } \\
\text { capreolus }\end{array}$ & M2 & $\mathrm{R}$ & buccal, mesial lobe & bulk & 0.707713 & 0.000010 \\
\hline RM2 & RM2Sr-13 & A135-7 & $\begin{array}{l}\text { Capreolus } \\
\text { capreolus }\end{array}$ & $\mathrm{dp} 3$ & $\mathrm{~L}$ & buccal lobe, whole tooth & bulk & 0.707923 & 0.000016 \\
\hline RM3 & RM3Sr-15 & A135-17 & $\begin{array}{l}\text { Capreolus } \\
\text { capreolus }\end{array}$ & M2 & $\mathrm{L}$ & buccal, mesial lobe & bulk & 0.707857 & 0.000009 \\
\hline RM4 & RM4Sr-12 & A135-11 & $\begin{array}{l}\text { Capreolus } \\
\text { capreolus }\end{array}$ & $\mathrm{dp} 4$ & $\mathrm{~L}$ & lingual, distal lobe & bulk & 0.707855 & 0.000008 \\
\hline
\end{tabular}


K.J. Gron et al. MEETING IN THE FOREST: HUNTERS \& FARMERS AT THE CONEYBURY 'ANOMALY', WILTSHIRE

TABLE 7: TOOTHWEAR \& ERUPTION-BASED AGE ESTIMATION FOR SAMPLED MANDIBLES

\begin{tabular}{|c|c|c|c|c|c|c|}
\hline $\begin{array}{l}\text { Specimen } \\
\text { no. }\end{array}$ & Species & $\begin{array}{c}\text { Element } \\
\text { (all teeth mandibular) }\end{array}$ & Side & Age & Method & $\delta^{34} S$ \\
\hline CM7 & Bos taurus & mandible with $\mathrm{dp} 3, \mathrm{dp} 4$, unerupted $\mathrm{M} 1$ & $\mathrm{~L}$ & $<1$ month & Legge 1992 & 11.7 \\
\hline CM9 & Bos taurus & $\begin{array}{l}\text { mandible with } \mathrm{dp} 2, \mathrm{dp} 3, \mathrm{dp} 4 \text {, unerupted } \\
\text { M1 }\end{array}$ & $\mathrm{L}$ & $<1$ month & Legge 1992 & 11.9 \\
\hline CM2/CM5 & Bos taurus & mandible with dp4, M1, unerupted M2 & $\mathrm{R}$ & 6-15 months & Legge 1992 & 9.7 \\
\hline CM8 & Bos taurus & mandible with dp2, dp3, dp4, M1 & $\mathrm{R}$ & 6-15 months & Legge 1992 & 13.3 \\
\hline CM1 & Bos taurus & mandible with dp3, dp4, M1, M2 & $\mathrm{R}$ & 15-26 months & Legge 1992 & 11.0 \\
\hline CM4 & Bos taurus & mandible with dp3, dp4 & $\mathrm{L}$ & $<26$ months & Legge 1992 & 13.3 \\
\hline CM12 & Bos taurus & mandible with M3 & $\mathrm{R}$ & $>26$ months & Legge 1992 & 11.7 \\
\hline CM10 & Bos taurus & mandible with P4, M1, M2, M3 & $\mathrm{L}$ & $3-6$ years & Legge 1992 & 9.3 \\
\hline RM2 & $\begin{array}{l}\text { Capreolus } \\
\text { capreolus }\end{array}$ & mandible with $\mathrm{dp} 2, \mathrm{dp} 3$ & $\mathrm{~L}$ & $<1$ year & $\begin{array}{l}\text { Noe-Nygaard } \\
1987\end{array}$ & 14.1 \\
\hline RM4 & $\begin{array}{l}\text { Capreolus } \\
\text { capreolus }\end{array}$ & mandible with $\mathrm{dp} 3$ and $\mathrm{dp} 4$ & $\mathrm{~L}$ & $<1$ year & $\begin{array}{l}\text { Noe-Nygaard } \\
1987\end{array}$ & 13.6 \\
\hline RM3 & $\begin{array}{l}\text { Capreolus } \\
\text { capreolus }\end{array}$ & mandible with $\mathrm{M} 1, \mathrm{M} 2, \mathrm{M} 3$ & $\mathrm{~L}$ & $1-2$ years & Aitkin 1975 & 14.3 \\
\hline RM1 & $\begin{array}{l}\text { Capreolus } \\
\text { capreolus }\end{array}$ & mandible with M2, M3 & $\mathrm{R}$ & $3-5$ years & Aitkin 1975 & 14.5 \\
\hline
\end{tabular}

Loose teeth or mandibles with only one tooth are omitted

\section{Strontium and sulphur: discussion}

Neither the strontium nor the sulphur isotope data tell us precisely where the animals came from, but they do give an impression of the scale of movement. From Coneybury, one must travel at least $20 \mathrm{~km}$ in order to reach a different strontium isotope biosphere (Evans et al. 2010), and depending on the direction, substantially larger distances. All animals are consistent with the chalk biosphere of the Chalk biosphere of Wiltshire, so they likely lived no more than $20 \mathrm{~km}$ from Coneybury. However, the sulphur data indicate that the cattle were from different places within this catchment. Cattle can travel c. $15 \mathrm{~km}$ per day at a walking pace (Henlein 1954; Western \& Finch 1986), so it is possible that the cattle assembled for the Event left their respective homes on the day they were killed.

There has been much debate regarding the degree of residential and economic mobility in the Early Neolithic of Britain (Whittle 1997; Harris 2009), the general impression being that farmers lived a relatively mobile lifestyle (Harris 2009). Coneybury is not a settlement, and therefore does not directly relate to 'ordinary' agricultural production, and thus provides only limited information in this regard. The data regarding scale of movement are however relevant. It is likely that no animal at Coneybury originated further than a day's walk away. It is also unlikely that any of the animals lived any part of their lives outside this general radius. The lack of correlation between the ontogenetic age of the cattle and their $\delta^{34} \mathrm{~S}$ values demonstrates that several groups of animals, each from a particular place and comprised of individuals of multiple ages, travelled to the Event. When taken in conjunction with very similar dietary $\delta^{13} \mathrm{C}$ values indicating feeding in relatively homogeneous environments, on at least a sub-decade chronological scale there is no evidence to suggest cattle, and therefore farmer mobility, except to the Event.

\section{Carbon, nitrogen, \& the animals' dietary niches}

We determined $\delta^{13} \mathrm{C}$ and $\delta^{15} \mathrm{~N}$ values from the same mandibles and postcranial elements as were analysed for $\delta^{34} \mathrm{~S}$ values. These isotopes provide information on the animals' dietary niches. $\delta^{13} \mathrm{C}$ values can show whether the animals grazed on open ground or in forest, while $\delta^{15} \mathrm{~N}$ values can document whether the animals were ingesting food that came from manured fields (Gron \& Rowley-Conwy 2017).

$\delta^{13} \mathrm{C}$ values from Early Neolithic deer and cattle in southern Scandinavia demonstrate that cattle grazed almost exclusively on open ground, while red and roe deer grazed both in open ground and in forests. This implies that the clearings were small, because there is little or no evidence for clearings in the pollen diagrams in the earliest part of the Neolithic 
(Gron \& Rowley-Conwy 2017). The Coneybury $\delta^{13} \mathrm{C}$ values are plotted against the $\delta^{34} \mathrm{~S}$ in Figure 11. A value of c. $-22.5 \%$ is usually taken as a general threshold: diets deriving from closed-canopy forested environments are below this value (to the left in Fig. 11), while those from more open environments are above it (Drucker et al. 2003; Gron \& Rowley-Conwy 2017). The Coneybury cattle exhibit no $\delta^{13} \mathrm{C}$ values lower than $-22.7 \%$, indicating that they were feeding in open environments with little, if any, feeding on plant material from closed-canopy forests. This is despite the presence of forest environments in the landscape, as the roe deer diets clearly show: the Coneybury roe deer form an almost entirely separate group, with just two individuals among the cattle; the rest were apparently feeding entirely in forest. This result differs somewhat from the southern Scandinavian picture, where a greater proportion of red and roe deer were grazing open ground similar to the cattle (Gron \& Rowley-Conwy 2017).

This raises the question of how complete the forest cover was around Coneybury in the earliest Neolithic. Pollen cannot currently resolve this: pollen preservation in the chalklands is variable, often poor. Some pollen has been recovered from a variety of sites, but the profiles are largely undated with major hiatuses, making it difficult to gain a view of the landscape in the earliest Neolithic (Scaife forthcoming). It has until recently been assumed that forest cover on the chalklands was more or less continuous, but there are indications from lines of evidence such as beetles and snails that there may have been some open areas, albeit of indeterminate extent (Allen \& Gardiner 2009; Alexander et al. 2018). A better indicator of the environment within $20 \mathrm{~km}$ of Coneybury perhaps comes from our roe deer $\delta^{13} \mathrm{C}$ values. Roe deer adapt well to an open or semi-open agricultural landscape, and had there been clearings of any size we should expect more of the roe deer to have $\delta^{13} \mathrm{C}$ values overlapping those of the cattle. There is little such overlap, suggesting that the roe deer were grazing apart from the cattle, largely in forests.

$\delta^{15} \mathrm{~N}$ values are an indicator of trophic level, often used to reveal the degree of carnivory among various species, particularly humans and dogs. Among obligate herbivores like cattle and roe deer in temperate maritime environments, higher $\delta^{15} \mathrm{~N}$ values can probably only result from the animals eating foods that have been manured. The manuring of cereal crops is documented in the earliest Neolithic of both Britain
(Bogaard et al. 2013; Jones and Bogaard 2017) and Sweden (Gron et al. 2017). The possibility that manured foods might be fed to the cattle cannot therefore be ruled out.

At Coneybury, $\delta^{15} \mathrm{~N}$ values were similar in cattle and roe deer (Fig. 11), suggesting that the cattle were not ingesting manured foods. The highest $\delta^{15} \mathrm{~N}$ value obtained from cattle was $5.0 \%$, with average values lower, at $4.0 \%$. If trophic level enrichment is very conservatively estimated at 3\%o (Bocherens \& Drucker 2003 ) the diet of the cattle could not have consisted of plants with $\delta^{15} \mathrm{~N}$ values higher than $c .2 \%$. Manuring increases the $\delta^{15} \mathrm{~N}$ values of cereals by $3-6 \%$; this demonstrates that the Coneybury cattle were either not fed manured cereal hay, or that any hay they were fed had not been manured. The former scenario is more likely given the evidence now available for early Neolithic manuring of cereals in Britain (Bogaard et al. 2013; Jones and Bogaard 2017).

\section{EXPLAINING CONEYBURY}

\section{Summary}

The various lines of evidence put forward above indicate the following:

- only female cattle were killed (aDNA, biometry)

- the cattle were from at least three, perhaps four places (sulphur)

- the roe deer were all from one place (sulphur)

- all these places were on chalk or other limestones and probably within $20 \mathrm{~km}$ of Coneybury (strontium)

- cattle birth seasons were relatively concentrated, not spread through the year (carbon, oxygen)

- the cattle grazed on open ground (carbon)

- the cattle were not fed straw from manured cereal plots (nitrogen)

- cattle were butchered, and appendicular elements were removed (zooarchaeology)

- roe deer were butchered, appendicular elements were not removed (zooarchaeology)

- Coneybury contains uniquely high proportions of roe deer and blades/bladelets

So what was the Event that took place at Coneybury, and who was involved? 


\section{K.J. Gron et al. MEETING IN THE FOREST: HUNTERS \& FARMERS AT THE CONEYBURY 'ANOMALY', WILTSHIRE}

\section{What was the Event?}

The initial interpretation was that the Event was a butchery event associated with a feast, or a period of feasting (Richards 1990). This was based in part on the fact that the ceramic assemblage was abnormally large and diverse for a pit deposit (Cleal 1990; 2004). Approximately 41 ceramic vessels were recovered (Richards 1990), including bowls of various sizes, as well as cups. The vessels show a degree of similarity in manufacture that was interpreted to mean that they were made over a restricted period of time and the presence of larger fragments probably indicates that the vessels were not trampled after discard. Some of the potsherds were missing their outer surfaces. This was attributed to either exposure on a midden (eg weathering), but just as plausibly to post-depositional processes. However, such examples were few in number (Cleal 1990). The aggregate pottery-based evidence therefore points towards a short-lived depositional event, probably a feast, without strong indicators of prolonged activity (Cleal 1990; Richards 1990).

Other explanations have been put forth subsequently. One proposition is that the site is a Neolithic hunting camp in the same vein as Funnel Beaker Culture (TRB) hunting camps from the Scandinavian earliest Neolithic (Serjeantson 2014). However, the Scandinavian sites are of a very different character (see Gron \& Sørensen 2018), rendering this explanation not especially convincing. Some authors suggest a hybrid, a feast associated with a hunting event and (much more speculatively) a male maturation ritual (Sykes 2014, 61). Other interpretations have not focused on what the Event was, per se, but instead on the cultural processes underpinning the presence of the particular species of animals in the pit. One example suggests totemism (Reynolds 2012), while others suggest that the presence of wild species perhaps demonstrates a degree of economic continuity with the Mesolithic (Richards 1990). Regardless, an understanding of the character of the activities and participants is elusive.

In favour of the feasting interpretation is the fact that the pit is large and regular, with vertical sides (Fig. 2 ). Furthermore, it is not associated with a settlement but is an isolated 'one off' feature. The skeletal part representation of the animals offers further support. The differential treatment of the cattle and roe deer carcasses is unusual, but there are parallels. At the
Polish Neolithic site Bożejewice 22 for example, certain contexts, interpreted as deriving from community feasting, contained cattle remains that were missing their limbs; caprines from this site did not show this pattern (Marciniak 2005, 241-2). Another good comparison is the Mycenaean Bronze Age settlement on the hill of Tsoungiza at Ancient Nemea (Dabney et al. 2004). The bones from one particular deposit at the site (EU9) have been interpreted as the remains of a feast, containing the remains of both caprines and perhaps six (and likely more) cattle of varying ages, including newborns, juveniles, and adults. Importantly, the species were treated differently, with the limbs of the cattle being removed. The caprines were not treated in the same way. The EU9 deposit was interpreted as the remains of a large feast with many participants consuming cattle provided by a sponsor or sponsors, after which the cattle limbs were distributed to the villages from which those in attendance originated (Dabney et al. 2004).

The similarities between the faunal remains from Coneybury, Nemea, and Bożejewice 22 are remarkable. Figure 13 compares Coneybury and Nemea. Clearly, caprines and deer at these two sites were not treated in the same fashion as the cattle, possibly because they were simply an 'everyday' food, or were not 'valuable' enough for redistribution. However, the high incidence of marrow fracture at Coneybury (Maltby 1990) as well as at Nemea (Dabney et al. 2004) points to actual consumption at the site and not just butchery. Ethnographic records of the distribution and removal of meat at feasts are fairly common, for example pigs among the Massim and Kalam of New Guinea (Young 1971; Bulmer 1976); cattle among the Chin of Burma (Stevenson 1943); and buffalo among the Toraja of Sulawesi (Crystal 1974).

In aggregate, the isotopic and zooarchaeological evidence strongly suggests a regional feast at which groups from the surrounding area came together. We therefore concur with the original interpretation (Richards 1990), though we may be able to go further and suggest what type of feast was involved. Many recent discussions of feasts divide them into two fundamental types: solidarity (or alliance, or empowering) and promotional (or aggrandisive, competitive, or diacritical) (eg Dietler 2001; Hayden 2001; 2014; Adams 2004; Rowley-Conwy 2018). Solidarity feasts bring families or communities together to reinforce ties between them and all the participating 
THE PREHISTORIC SOCIETY

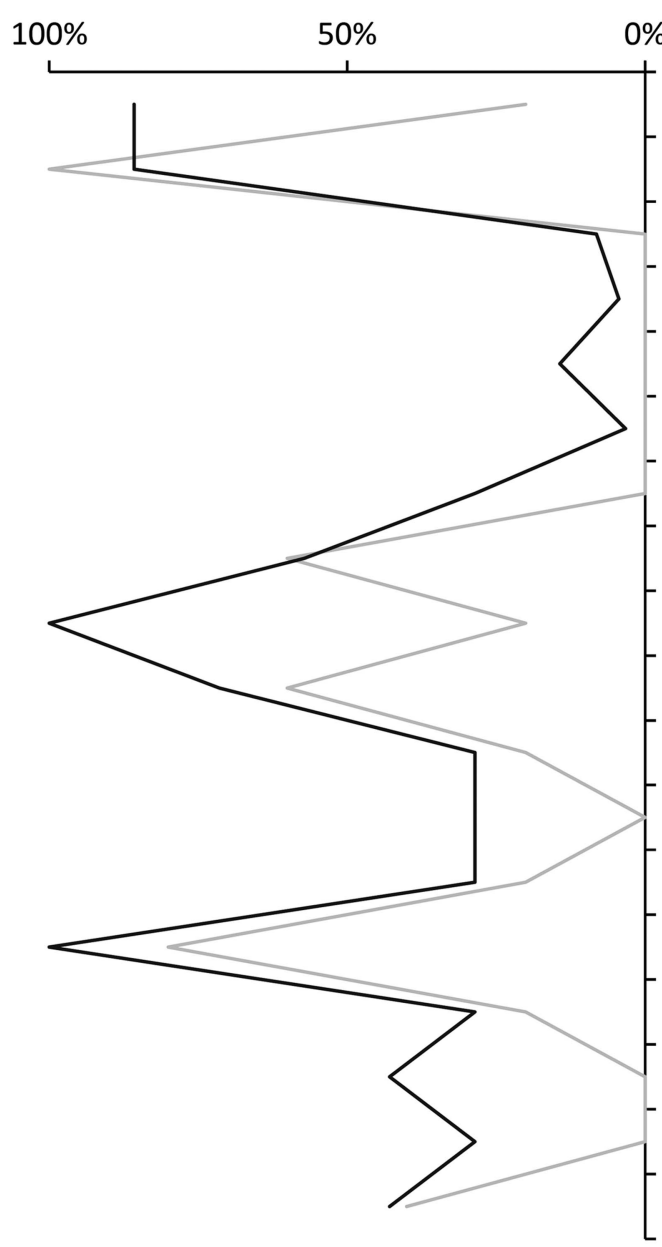

Caprines and Roe Deer

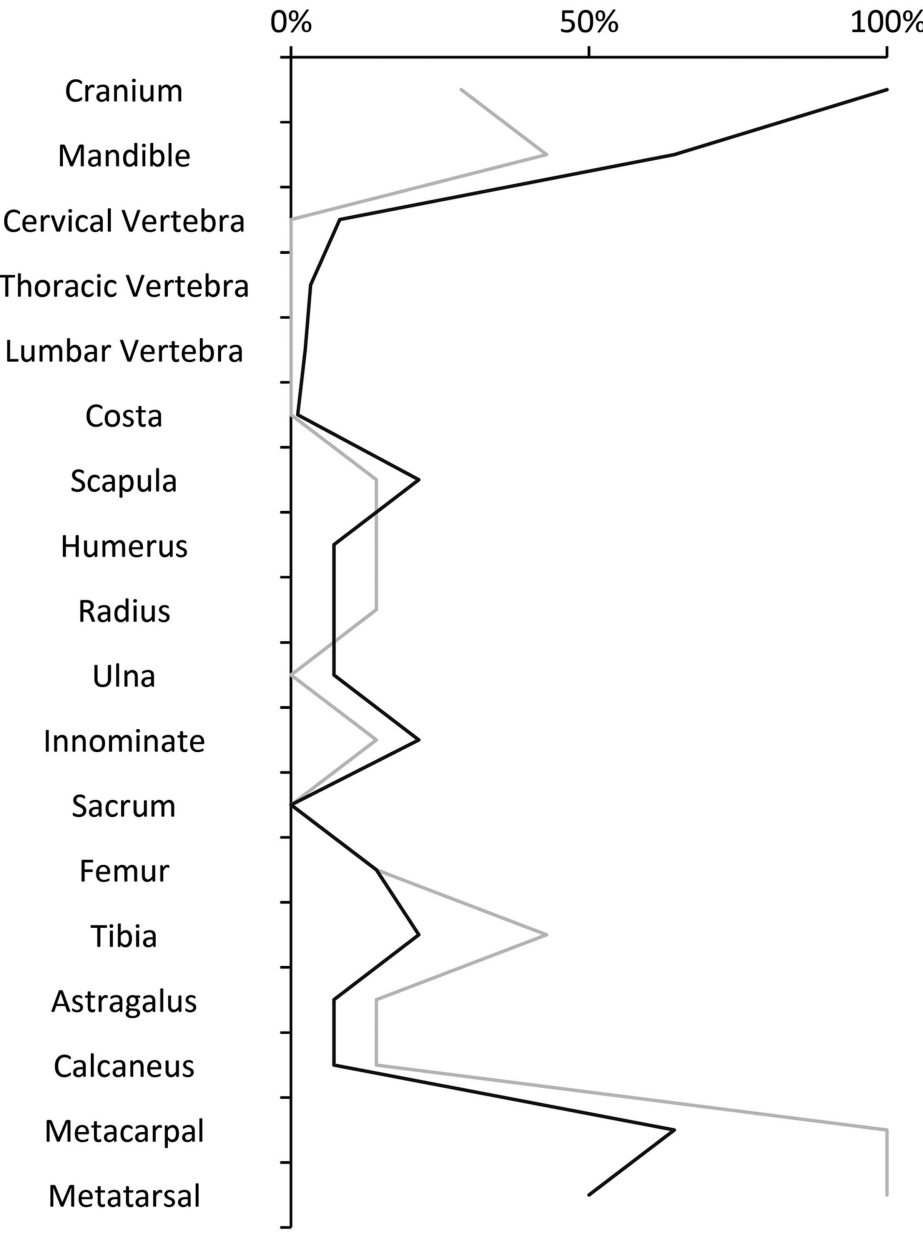

Cattle

Nemea

Coneybury

Fig. 13.

Derived \%MAU comparing Nemea \& Coneybury cattle, \& Nemea caprines with Coneybury roe deer. Dabney et al. (2004) list Minimum Numbers of Anatomical Units (MinAU), which is here considered synonymous with Minimum Animal Unit (MAU). Dabney et al. (2004) also list some different MinAU for proximal \& distal elements, so in these cases the larger of the two is taken for calculation. \%MAU is derived from both datasets in the same way sensu Gron (2015, 724) \& RowleyConwy (1998)

groups contribute food. Promotional feasts, in contrast, are designed to enhance the social status of the host, who provides the food in order to create obligations among the participants, who must repay the debt later through, for example, political support or military service. No feast is just one or the other, as politics always play a part (Dietler 2001), but the fundamental dichotomy is a useful basis. The specific type of feast depends on the distribution of people across the landscape and their perceived relations to each other. We have demonstrated that participants brought cattle from several different places to the Event, after which particular parts of cattle were probably redistributed. This is an argument in favour of the Event being a solidarity feast, which requires 'theoretically equal contributions' (Adams 2014, 61) from participants and serves to maintain community cohesion. As such, participants did not view themselves as members of different groups, but as members of one group scattered across the landscape, all within 
K.J. Gron et al. MEETING IN THE FOREST: HUNTERS \& FARMERS AT THE CONEYBURY 'ANOMALY', WILTSHIRE

about 1 day's walk from one another. If this is correct, the regional feasts that have been suggested for the causewayed enclosures (eg Thomas 2013) were already taking place in the earliest Neolithic phase, albeit on a smaller geographical scale.

Recent evidence from Britain suggests substantial individual human movement in the Early Neolithic over scales in excess of what we see at Coneybury (Neil et al. 2017), so communities such as the one which participated in the Event were almost certainly in contact with one another, possibly through intermarriage, migration, or other mechanisms.

\section{Who was at the Event?}

The interpretation of Coneybury centres on the question of identifying who was involved, using the animals as a proxy. We have identified three or perhaps four groups of farmers, who came together for a feast and deposited the remains in a large speciallycut pit.

Who contributed the roe deer? We advance two alternative hypotheses to answer this.

Scenario \#1. One of the groups of farmers brought the roe deer in addition to their cattle. This would have to be farming group a, because the sulphur isotope values in their cattle are the only ones that match the roe deer (Fig. 8). In this hypothesis, the farmers would have killed the roe deer in the forest around their settlement, and carried the carcasses to Coneybury presumably at the same time as they drove their cattle there.

There are two problems with Scenario \#1. First, it requires unique behaviour on the part of farming group a. None of the other Coneybury farmers brought roe deer to the Event, and no other Neolithic site anywhere in Britain (or for that matter the near continent) has this proportion of wild deer in an assemblage dominated by domesticates. Second, it does not account for the other unique aspect of Coneybury: the large proportion of blades/bladelets. We therefore advance an alternative suggestion.

Scenario \#2. One of the groups who attended the Event was not a farming group, but was a group of hunter-gatherers. The evidence for the appearance of agriculture is increasingly suggesting an abrupt transition, not a long-drawn-out one. This is likely to indicate the immigration of small groups of farmers (eg Rowley-Conwy 2004; 2011; Sheridan 2010). If this is correct, it begs the question of what became of the indigenous hunter-gatherers. In southern Scandinavia the relatively dense hunter-gatherer population apparently lived on in separate communities for several centuries, before fusing culturally and possibly biologically with the immigrant farmers (Gron \& Sørensen 2018). We have no comparable evidence from Britain; but if the indigenous hunter-gatherers did not immediately disappear when the farmers arrived, then contact is feasible between the indigenes and the immigrants. This suggestion accounts for the presence of both the roe deer and the blades/bladelets at Coneybury.

In this scenario the aggregate evidence would thus speak to negotiation and blending; wild and domestic animals, Neolithic and 'Mesolithic' technologies, and a new form of community activity all represented at Coneybury. Such negotiation is characteristic of landscapes where people of multiple geographic and cultural origins find themselves (Rice 1977) and the result is often the emergence of a third, unique, cultural entity. Given the continental connections evident in burial traditions from Britain (Scarre 2015), it is not unreasonable to think of Coneybury as the material remains of a frontier farming community that interacted with a local hunter-gatherer group.

Notwithstanding the above, farmers were the main participants in the Event. Cattle are all of domestic stock, and had to have been provided by those that raised them. The fact that all animals were female probably indicates that each individual contributing group of farmers simply contributed one or several of their, possibly underperforming, dairy cattle. Perhaps all attending groups were expected to provide a certain measure of meat, and the contribution of one group was in the form of roe deer.

How many roe deer equal a cow? This deceptively simple question encompasses perception, fact, and technology. Today, we know female cattle (dependent on various factors) weigh around $700 \mathrm{~kg}$, roe deer no more than $25 \mathrm{~kg}$ (Fruziński et al. 1982). By this measure, 28 roe deer equal a cow. In the absence of the technology to weigh a large animal, however, how would it be possible to know? An estimate would have to suffice and, perhaps, seven roe deer were perceived to equal a cow. Another option is simply that the group contributing the deer could not carry more than seven animals.

The redistributive nature of the feast, and the fact communities from different places all brought 
contributions, identifies Coneybury as the material remains of a solidarity feast. The Early Neolithic date and the community nature of the Event indicate that the Salisbury Plain hosted smaller-scale community gatherings from the earliest Neolithic and allows identification of community networks of frontier farmers in place from the beginning of agriculture in Britain. There has been some discussion of the role of networks, interconnected groups, interactive spheres, and mobility in prehistory, including in the British Neolithic (Whittle 1997; Edmonds 1999; Harris 2009; 2014; Cummings \& Harris 2011). Much of this discussion, however, has been on theoretical and epistemological bases (Harris 2009). Despite this, there is no doubt that such networks and communities would have been formed quickly from the start of the Neolithic (Sheridan 2010) and these discussions need to occur. It is in this context that Coneybury presents hard evidence regarding the nature and scale of an Early Neolithic community event, and as such, the community itself.

\section{CONCLUSIONS}

We have argued on the basis of multiple lines of evidence that Coneybury represents the material remains of a gathering organised by a regional community, with participants from different areas. Farmers from different farms brought their cattle, all raised in a similar fashion and probably deriving from normal agricultural production, to the Event. One group of attendees provided roe deer instead of, or in addition to, cattle. We believe that the most likely scenario is that this group comprised local hunter-gatherers who survived (for a short time at least) alongside the immigrant farmers, and formed part of the local regional group.

We hope that we have illustrated the power of the latest suite of scientific techniques to answer archaeological questions. The use of multiple techniques in combination represents we believe a powerful way of moving forward our understanding of the earliest farming communities in Britain.

Acknowledgements: We first acknowledge the Leverhulme Trust for research funding under Grant RPG-2016-081. We also sincerely thank Adrian Green and the Salisbury Museum for access to the Coneybury material. We thank Julian Richards, the excavator of the site, for his input. Additional thanks are owed to Sandra Timsic and Jo Peterkin for their work preparing and analysing the enamel carbon and oxygen, and enamel strontium respectively. Rob Scaife sent us his forthcoming pollen volume, and Miranda Armour-Chelu sent us the cattle measurements from the causewayed enclosure at Etton; thanks to both for permission to cite their unpublished work. Thanks are also due to three anonymous referees as well as two anonymous colleagues, whose comments have materially improved this paper. Josh Pollard pointed us towards recent work on stone tool assemblages. We further thank Ben Chan for a copy of, and permission to cite, his forthcoming chapter on the lithic material of the Stonehenge landscape. Historic England kindly provided permission to reproduce the plan and section drawing from the original publication. Lastly, we gratefully acknowledge a NERC Strategic Environmental Science Capital Call grant (\#CC018) that provided funding for the purchase of a dedicated sulphur isotope IRMS in the Stable Isotope Biogeochemistry Laboratory (SIBL) at Durham University.

\section{SUPPLEMENTARY MATERIAL}

To view supplementary material for this article, please visit https://doi.org/10.1017/ppr.2018.15

\section{BIBLIOGRAPHY}

Adams, R.L. 2004. An ethnoarchaeological study of feasting in Sulawesi, Indonesia. Journal of Anthropological Archaeology 23, 56-78

Aitkin, R.J. 1975. Cementum layers and tooth wear as criteria for ageing roe deer (Capreolus capreolus). Journal of Zoology 171(1), 15-28

Alexander, J. 1961. The excavation of the Chestnuts megalithic tomb at Addington, Kent. Archaeologia Cantiana 76, 1-57

Alexander, K., Allen, M., Butler, J., Green, T. \& Woods, R. 2018. Britain's natural landscapes - promoting improved understanding of the nature of the post-glacial vegetation of lowland Britain. British Wildlife June 2018, 330-8

Allen, M.J. and Gardiner, J. 2009. If you go down to the woods today: a re-evaluation of the chalkland postglacial woodland; implications for prehistoric communities. In M.J. Allen, N. Sharples \& T. O'Connor (eds), Land and People. Papers in Memory of John G. Evans, 49-66. Oxford: Prehistoric Society Research Paper 2

Allen, M.J. \& Green, M. 1998. The Fir Tree Field shaft: the date and archaeological and palaeo-environmental potential of a chalk swallowhole feature. Proceedings of the Dorset Natural History o Archaeological Society 120, 25-38

Allen, T., Barclay, A., Cromarty, A.M., AndersonWhymark, H., Parker, A., Robinson, M. \& Jones, G. 2013. Opening the Wood, Making the Land. The Archaeology of a Middle Thames Landscape: the Eton College Rowing Course and the Maidenhead, Windsor and Eton Flood Alleviation Scheme. Vol I: Mesolithic to Early Bronze Age. Oxford: Thames Valley Landscapes Monograph 38 


\section{K.J. Gron et al. MEETING IN THE FOREST: HUNTERS \& FARMERS AT THE CONEYBURY 'ANOMALY', WILTSHIRE}

Balasse, M, \& Tresset, A. 2007. Environmental constraints on the reproductive activity of domestic sheep and cattle: what latitude for the herder? Anthropozoologica 42(2), 71-88

Balasse, M., Boury, L., Ughetto-Monfrin, J., \& Tresset, A. 2012. Stable isotope insights $\left(\delta^{18} \mathrm{O}, \delta^{13} \mathrm{C}\right)$ into cattle and sheep husbandry at Bercy (Paris, France, 4th millennium bC): birth seasonality and winter leaf foddering. Environmental Arcabeology 17(1), 29-44

Balasse, M., Tresset, A., Bălăşescu, A., Blaise, E., Tornero, C., Gandois, H., Fiorillo, D., Nyerges, É.Á., Frémondeau, D., Banffy, E., \& Ivanova, M. 2017. Animal board invited review: sheep birth distribution in past herds: a review for prehistoric Europe (6th to 3rd millennia BC). Animal doi: 10.1017/S1751731117001045

Barclay, A., 2014. Re-dating the Coneybury Anomaly and its implications for understanding the earliest Neolithic pottery from southern England. Past 77, 11-3

Benson, D. and Whittle, A. 2007. Building Memories. The Neolithic Cotswold Long Barrow at Ascott-underWychwood, Oxfordshire. Oxford: Oxbow Books

Bishop, R.R., Church, M.J. \& Rowley-Conwy, P. 2010. Cereals, fruits and nuts in the Scottish Neolithic. Proceedings of the Society of Antiquaries of Scotland 139, 47-103

Bocherens, H. \& Drucker, D. 2003. Trophic level isotopic enrichment of carbon and nitrogen in bone collagen: case studies from recent and ancient terrestrial ecosystems. International Journal of Osteoarchaeology 13, 46-53

Bogaard, A., Fraser, R., Heaton, T.H.E., Wallace, M., Vaiglova, P., Charles, M., Jones, G., Evershed, R.P., Styring, A.K., Andersen, N.H., Arbogast, R.-M., Bartosiewicz, L., Gardeisen, A., Kanstrup, M., Maier, U., Marinova, E., Ninov, L., Schäfer, M. \& Stephan, E. 2013. Crop manuring and intensive land management by Europe's first farmers. Proceedings of the National Academy of Sciences 110(31), 12589-94

Bradley, R., Over, D.W., Startin, D.W.A. \& Weng, R. 1976. The excavation of a Neolithic site at Cannon Hill, Maidenhead, Berkshire. Berkshire Archaeological Journal 68, 5-19

Britnell, W.J. \& Savory, H.N. 1984. Gwernvale and Penywyrlod: two Neolithic Long Cairns in the Black Mountains of Brecknock. Cardiff: Cambrian Archaeological Monographs 2

Britton, K. 2017. A stable relationship: isotopes and bioarchaeology are in it for the long haul. Antiquity 91 (358), 853-64

Brown, W.A.B., Christofferson, P.V., Massler, M. \& Weiss, M.B. 1960. Postnatal tooth development in cattle. American Journal of Veternary Research 21, 7-34

Bulmer, R. 1976. Selectivity in hunting and in disposal of animal bone by the Kalam of the New Guinea Highlands. In G. de G. Sieveking, I.H. Longworth \& K.E. Wilson (eds), Problems in Economic and Social Archaeology, 169-86. London: Duckworth.

Casteel, R.W. \& Grayson, D.K. 1977. Terminological problems in quantitative faunal analysis. World Archaeology 9(2), 235-42
Chan, B. forthcoming. Investigating traditions of stone working and inhabitation in the Stonehenge landscape: the lithic assemblages of the Stonehenge Riverside Project. In M. Parker Pearson, J. Pollard, C. Richards, J. Thomas $\&$ K. Welham (eds), Stonehenge for the Ancestors. Part II: Syntheses. The Stonehenge Riverside Project Volume 2. Leiden: Sidestone

Cleal, R. 1990. The prehistoric pottery. In Richards 1990, 45-57

Cleal, R. 2004. The dating and diversity of the earliest ceramics of Wessex and south-west England. In R. Cleal \& J. Pollard (eds), Monuments and Material Culture. Papers in Honour of an Avebury Archaeologist: Isobel Smith, 164-92. Salisbury: Hobnob

Cramp, L., Jones, J., Sheridan, A., Smyth, J., Whelton, H., Mulville, J., Sharples, N.M. \& Evershed, R.P. 2014. Immediate replacement of fishing with dairying by the earliest farmers of the northeast Atlantic archipelagos. Proceedings of the Royal Society B 281, 1-8

Crystal, E. 1974. Cooking pot politics: a Toraja village study. Indonesia 18, 118-51.

Cummings, V. \& Harris, O. 2011. Animals, people and places: the continuity of hunting and gathering practices across the Mesolithic-Neolithic transition in Britain. European Journal of Archaeology 14(3), 36182

Dabney, M.K., Halstead, P. \& Thomas, P. 2004. Mycenaean feasting on Tsoungiza at ancient Nemea. Hesperia: The Journal of the American School of Classical Studies at Athens 73(2), 197-215

Degerbøl, M. \& Fredskild, B. 1970. The Urus (Bos primigenius Bojanus) and Neolithic domesticated cattle (Bos taurus domesticus Linné) in Denmark. Copenhagen: Det Kongelige Dansk Videnskabernes Selskab

DeNiro, M.J. 1985. Postmortem preservation and alteration of in vivo bone collagen isotope ratios in relation to palaeodietary reconstruction. Nature 317 , 806-9

Dietler, M. 2001. Theorizing the feast: rituals of consumption, commensal politics, and power in African societies. In M. Dietler \& B. Hayden (eds), Feasts. Archaeological and Ethnographic Perspectives on Food, Politics, and Power, 65-114. Washington DC: Smithsonian Institution.

Drucker, D., Bocherens, H., Bridault, A. \& Billiou, D. 2003. Carbon and nitrogen isotopic composition of red deer (Cervus elaphus) collagen as a tool for tracking palaeoenvironmental change during the Late-Glacial and Early Holocene in the northern Jura (France). Palaeogeography, Paleoclimatology, Paleoecology 195, 375-88

Edmonds, M. 1999. Ancestral Geographies of the Neolithic. London: Routledge

Evans, C. \& Hodder, I. 2006. A Woodland Archaeology. Neolithic Sites at Haddenham. Haddenham Project 1. Cambridge: McDonald Institute

Evans, J. \& Smith, I. 1983. Excavations at Cherhill, North Wiltshire. Proceedings of the Prehistoric Society 49, 43-117 
Evans, J.A., Montgomery, J., Wildman, G. \& Boulton, N. 2010. Spatial variations in biosphere ${ }^{87} \mathrm{Sr} /{ }^{86} \mathrm{Sr}$ in Britain. Journal of the Geological Society, London 167, 1-4

Ford, S. 1987. Chronological and functional aspects of flint assemblages. In A.G. Brown \& M.R. Edmonds (eds), Lithic Analysis and Later British Prehistory: Some problem and approaches, 67-85. Oxford: British Archaeological Report 162

Fricke, H.C., Clyde, W.C. \& O’Neil, J.R. 1998. Intra-tooth variations in $\delta^{18} \mathrm{O}\left(\mathrm{PO}_{4}\right)$ of mammalian tooth enamel as a record of seasonal variations in continental climate variables. Geochimica et Cosmochimica Acta 62(11), 1839-50

Fruziński, B., Kałuziński, J. \& Baksalary, J. 1982. Weight and body measurements of forest and field roe deer. Acta Theriologica 27(33), 479-88

Gerling, C., Doppler, T., Heyd, V., Knipper, C., Kuhn, T., Lehmann, M.F., Pike, A.W.G. \& Schibler, J. 2017. Highresolution isotopic evidence of specialized cattle herding in the European Neolithic. PLoS One 12(7):e0180164

Gilbert, M.T.P., Hansen, A.J., Willerslev, E., Rudbeck, L., Barnes, I., Lynnerup, N. \& Cooper, A. 2003. Characterization of genetic miscoding lesions caused by postmortem damage. American Journal of Human Genetics 72, 48-61

Grigson, C. 1965. Measurements of bones, horncores, antlers, and teeth. In I. Smith (ed.) Windmill Hill and Avebury: Excavations by Alexander Keiller 1925-39, 145-67. Oxford: Clarendon

Grigson, C. 1983. Mesolithic and Neolithic animal bones. In Evans, \& Smith 1983, 64-72

Grigson, C. 1999. The mammalian remains. In A. Whittle, J. Pollard \& C. Grigson (eds), The Harmony of Symbols: the Windmill Hill causewayed enclosure, Wiltshire, 164-252. Oxford: Oxbow Books

Gron, K. 2015. Body part representation, fragmentation and patterns of Ertebølle deer exploitation in northwest Zealand, Denmark. International Journal of Osteoarchaeology 25, 722-32

Gron, K.J. \& Rowley-Conwy, P. 2017. Herbivore diets and the anthropogenic environment of early farming in southern Scandinavia. The Holocene 27(1), 98-109

Gron, K.J. \& Sørensen, L. 2018. Cultural and economic negotiation: a new perspective on the Neolithisation of southern Scandinavia. Antiquity 364, 958-74. https://doi. org/10.15184/aqy.2018.71

Gron, K.J., Montgomery, J. \& Rowley-Conwy, P. 2015. Cattle management for dairying in Scandinavia's earliest Neolithic. PLoS One 10(7): e0131267

Gron, K.J., Gröcke, D.R., Larsson, M. Sørensen, L., Larsson, L., Rowley-Conwy, P. \& Church, M.J. 2017. Nitrogen isotope evidence for manuring of Early Neolithic Funnel Beaker culture cereals from Stensborg, Sweden. Journal of Archaeological Science Reports 14, 575-9

Gron, K.J., Montgomery, J., Nielsen, P.O., Nowell, G.M., Peterkin, J.L., Sørensen, L. \& Rowley-Conwy, P. 2016. Strontium isotope evidence of early Funnel Beaker Culture movement of cattle. Journal of Archaeological Science: Reports 6, 248-51
Halstead, P. 1998. Mortality models and milking: problems of uniformitarianism, optimality and equifinality reconsidered. Anthropozoologica 27, 3-20

Halstead, P. \& Isaakidou, V. 2017. Calf mortality and milking: was Tony Legge right after all? In P. RowleyConwy, D. Serjeantson \& P. Halstead (eds), Economic Zooarchaeology. Studies in hunting, herding and early agriculture, 119-25. Oxford: Oxbow Books

Harris, O. 2009. Making places matter in early Neolithic Dorset. Oxford Journal of Archaeology 28(2), 111-23

Harris, O.J.T. 2014. (Re)assembling communities. Journal of Archaeological Method and Theory 21, 76-97.

Hayden, B. 2001. Fabulous feasts: a prolegomenon to the importance of feasting. In M. Dietler \& B. Hayden (eds), Feasts: Archaeological and ethnographic perspectives on food, politics, and power, 23-64. Washington, DC: Smithsonian Institution

Hayden, B. 2014. The Power of Feasts from Prehistory to the Present Day. Cambridge: Cambridge University Press.

Henlein, P.C. 1954. Cattle driving from the Ohio country, 1800-1850. Agricultural History 28(2), 83-95.

Higham, C.F.W. 1969. The metrical attributes of two samples of bovine limb bones. Journal of Zoology (London) 157, 63-74

Jacques, D., Phillips, T. \& Lyons, T. 2018. Blick Mead: Exploring the 'First Place' in the Stonehenge Landscape. Archaeological Excavations at Blick Mead, Amesbury, Wiltshire 2005-2016. Oxford: Peter Lang

Jay, M., Montgomery, J., Nehlich, O., Towers, J. \& Evans, J. 2013. British Iron Age chariot burials of the Arras culture: a multi-isotope approach to investigating mobility levels and subsistence practices. World Archaeology 45(3), 473-91

Jones, G. 2013. Early Neolithic animal bone from Area 6. In Allen et al. 2013, 183-98

Jones, G. \& Bogaard, A. 2017. Integration of cereal cultivation and animal husbandry in the British Neolithic: the evidence of charred plant remains from timber buildings at Lismore Fields. In P. Rowley-Conwy, D. Serjeantson, \& P. Halstead (eds), Economic Zooarchaeology. Studies in hunting, herding and early agriculture, 221-6. Oxford: Oxbow Books

Jones, G. \& Rowley-Conwy, P. 2007. On the importance of cereal cultivation in the British Neolithic. In S. Colledge \& J. Conolly (eds), The Origins and Spread of Domestic Plants in Southwest Asia and Europe, 391-419. Walnut Creek, California: Left Coast Press/University College London Institute of Archaeology

Legge, A.J. 1981. Aspects of cattle husbandry. In R. Mercer (ed.), Farming Practice in British Prehistory, 169-81. Edinburgh: Edinburgh University Press

Legge, A. J. 1992. Excavations at Grimes Graves, Norfolk, 1972-1976, Fascicule 4: Animals, Environment and the Bronze Age Economy. London: British Museum Press.

Legge, A.J. 2008. Livestock and Neolithic society at Hambledon Hill. In R. Mercer \& F. Healy (eds), Hambledon Hill, Dorset, England. Excavation and Survey of a Neolithic Monument Complex and its 


\section{K.J. Gron et al. MEETING IN THE FOREST: HUNTERS \& FARMERS AT THE CONEYBURY 'ANOMALY', WILTSHIRE}

Surrounding Landscape, 536-85. Swindon: English Heritage

Levitan, B. 1990. The non-human vertebrate remains. In Saville (ed.) 1990, 199-213

Maltby, M. 1990. Animal bones. In Richards 1990, 57-61

Maltby, M. 1991. The animal bones. In Woodward (ed.) 1991, 105-6

Manby, T.G. 1965. The excavation of Green Low chambered tomb. Derbyshire Archaeological Journal 85, $1-24$

Marciniak, A. 2005. Placing Animals in the Neolithic: Social zooarchaeology of prehistoric farming communities. London: UCL Press

Montgomery, J., Budd, P. \& Evans, J. 2000. Reconstructing the lifetime movements of ancient people: a Neolithic case study from southern England. European Journal of Archaeology 3, 370-85

Montgomery, J., Evans, J.A. \& Towers, J. forthcoming. Strontium isotopic analysis. In Parker Pearson, M., Chamberlain, A., Jay, M., Richards, M., Evans, J. \& A. Sheridan, (eds), The Beaker People: Isotopes, mobility and diet in prehistoric Britain. Oxford: Prehistoric Society Research Paper 7

Morellet, N., Van Moorter, B., Cargnelutti, B., Angibault, JM., Lourtet, B., Merlet, J., Ladet, S. \& Hewison, A.J.M. 2011. Landscape composition influences roe deer habitat selection at both home range and landscape scales. Landscape Ecology 26, 999-1010

Mulville, J. \& Grigson, C. 2007. The animal bones. In Benson \& Whittle (eds) 2007, 237-53

Nehlich, O. 2015. The application of sulphur isotope analyses in archaeological research: a review. EarthScience Reviews 142, 1-17

Nehlich, O. \& Richards, M.P. 2009. Establishing collagen quality criteria for sulphur isotope analysis of archaeological bone collagen. Archaeological and Anthropological Sciences 1, 59-75

Neil, S., Montgomery, J., Evans, J., Cook, G.T. \& Scarre, C. 2017. Land use and mobility during the Neolithic in Wales explored using isotope analysis of tooth enamel. American Journal of Physical Anthropology 164, 371-93

Noe-Nygaard, N. 1987. Taphonomy in archaeology with special emphasis on man as a biasing factor. Journal of Danish Archaeology 6, 7-62

Noe-Nygaard, N., Price, T.D. \& Hede, S.U. 2005. Diet of aurochs and early cattle in southern Scandinavia: evidence from ${ }^{15} \mathrm{~N}$ and ${ }^{13} \mathrm{C}$ stable isotopes. Journal of Archaeological Science 32, 855-71

Nyegaard, G. 1985. Faunalevn fra yngre stenalder på øerne syd for Fyn. In J. Skaarup (ed.), Yngre Stenalder på Øerne syd for Fyn, 426-57. Rudkøbing: Langelands Museum

Parker Pearson, M., Pollard, J., Richards, C., Thomas, J. \& Welham, K. 2015. Stonehenge. Making Sense of a Prehistoric Mystery. York: Council for British Archaeology

Price, T.D., Meiggs, D., Weber, M-J. \& Pike-Tay, A. 2015. The migration of Late Pleistocene reindeer: isotopic evidence from northern Europe. Archaeological and Anthropological Sciences 9(3), 371-94
Reynolds, F. 2012. Totemism and food taboos in the early Neolithic: a feast of roe deer at the Coneybury 'Anomaly', Wiltshire, southern Britain. In H. Anderson-Whymark \& J. Thomas (eds), Regional Perspectives on Neolithic pit deposition: Beyond the mundane, 171-86. Oxford: Neolithic Studies Group Seminar Papers 12

Rice, J.G. 1977. The role of culture and community in frontier prairie farming. Journal of Historical Geography $3(2), 155-75$

Richards, J. (ed.) 1990. The Stonehenge Environs Project. London: English Heritage Archaeological Reports 16/ York: Archaeology Data Service https://doi.org/ $10.5284 / 1028203$

Richmond, A. 1999. Preferred Economies. The Nature of the Subsistence Base throughout Mainland Britain during Prehistory. Oxford: British Archaeological Report 290

Rowley-Conwy, P. 1998. Meat, furs and skins: Mesolithic animal bones from Ringkloster, a seasonal hunting camp in Jutland. Journal of Danish Archaeology 12, 87-98

Rowley-Conwy, P. 2004. How the west was lost. A reconsideration of agricultural origins in Britain, Ireland and southern Scandinavia. Current Anthropology 45 supplement, S83-113

Rowley-Conwy, P. 2011. Westward Ho! The spread of agriculture from Central Europe to the Atlantic. Current Anthropology 52(S4), 431-51

Rowley-Conwy, P. 2013. North of the frontier: early domestic animals in northern Europe. In S. Colledge, J. Conolly, K. Conolly, K. Dobney, K. Manning \& S. Shennan (eds), The Origins and Spread of Domestic Animals in Southwest Asia and Europe, 283-311. Walnut Creek CA: Left Coast Press

Rowley-Conwy, P. 2018. Zooarchaeology and the elusive feast: from performance to aftermath. World Archaeology 50(1), doi: 10.1080/00438243.00432018.01445024

Rowley-Conwy, P. \& Legge, A.J. 2015. Subsistence practices in western and northern Europe. In C. Fowler, J. Harding $\&$ D. Hofmann (eds), The Oxford Handbook of Neolithic Europe, 429-6. Oxford: Oxford University Press

Saville, A. 1985. Review of Britnell and Savory 1984. Proceedings of the Prehistoric Society 51, 242-4

Saville, A. 1990. Hazleton North, Gloucestershire, 1979-82: Tthe excavation of a Neolithic long cairn of the CotswoldSevern group. London: English Heritage Archaeological Report 13

Saville, A. 2007. Review of Benson and Whittle 2007. Proceedings of the Prehistoric Society. http://www. prehistoricsociety.org/files/reviews/07_12_benson.htm (accessed 8 Nov 2017).

Scaife, R. forthcoming. The Pleistocene and Holocene Environment of southern England: A review of Pollen Studies with particular reference to Archaeology. London: English Heritage.

Scarre, C. 2015. Parallel lives? Neolithic funerary monuments and the Channel divide. In H. AndersonWhymark, D. Garrow \& F. Sturt (eds), Continental Connections: Exploring cross-channel relationships from the lower Palaeolithic to the Iron Age, 78-98. Oxford: Oxbow Books 
Serjeantson, D. 2011. Review of Animal Remains from the Neolithic and Early Bronze Age of southern Britain $(4000$ $B C-1500 \quad B C)$. London: English Heritage Research Department Report Series 29

Serjeantson, D. 2014. Survey of animal remains from southern Britain finds no evidence for continuity from the Mesolithic period. Environmental Archaeology 19, 256-62

Sharp, Z. 2007. Principles of Stable Isotope Geochemistry. Upper Saddle River NJ: Pearson Prentice Hall

Sheridan, A. 2010. The Neolithization of Britain and Ireland: the 'big picture'. In B. Finlayson \& G. Warren (eds), Landscapes in Transition, 89-105. Oxford: Council for British Research in the Levant Supplementary Series 8

Silver, I. A. 1969. The ageing of domestic animals. In D. Brothwell \& E.S. Higgs (eds), Science in Archaeology: A survey of progress and research, 283-302. London: Thames \& Hudson

Smyth, J. 2012. Breaking ground: an overview of pits and pit-digging in Neolithic Ireland. In $\mathrm{H}$. AndersonWhymark and J. Thomas (eds), Regional Perspectives on Neolithic Pit Deposition: Beyond the Mundane, 13-29. Oxford: Neolithic Studies Group Seminar Papers 12

Stevenson, H.N.C. 1943. The Economics of the Central Chin Tribes. Bombay: Times of India.

Sullivan, C.H. \& Krueger, H.W. 1981. Carbon isotope analysis of separate chemical phases in modern and fossil bone. Nature 292, 333-5

Svensson, E.M., Götherström, A. \& Vretemark, M. 2008. A DNA test for sex identification in cattle confirms osteometric results. Journal of Archaeological Science $35,942-6$

Sykes, N. 2014. Beastly Questions: Animal answers to archaeological issues. London: Bloomsbury Academic

Thomas, J. 1993. Discourse, totalization and 'The Neolithic'. In C. Tilley (ed.), Interpretative Archaeology, 357-94. Oxford: Berg

Thomas, J. 2013. The Birth of Neolithic Britain: An interpretive account. Oxford: Oxford University Press

Tilley, C. 1996. An Ethnography of the Neolithic. Cambridge: Cambridge University Press New Studies in Archaeology

Towers, J., Bond, J., Evans, J., Mainland, I. \& Montgomery, J. 2017. An isotopic investigation into the origins and husbandry of Mid-Late Bronze Age cattle from Grimes Graves, Norfolk. Journal of Archaeological Science: Reports 15, 59-72

Towers, J., Gledhill, A., Bond, J. \& Montgomery, J. 2014. An investigation of cattle birth seasonality using $\delta^{13} \mathrm{C}$ and $\delta^{18} \mathrm{O}$ profiles within first molar enamel. Archaeometry 56 (S1), 208-36
Towers, J., Jay, M., Mainland, I., Nehlich, O. \& Montgomery, J. 2011. A calf for all seasons? The potential of stable isotope analysis to investigate prehistoric husbandry practices. Journal of Archaeological Science 38, 1858-68

Tresset, A. and Vigne, J-D. 2006. Le dépôt d'animaux de la structure e4. In C-T. Le Roux, É. Gaumé, Y. Lecerf \& J-Y. Tinévez (eds), Monuments Mégalithiques à Locmariaquer (Morbiham). Le long Tumulus d'Er Grah dans son Environnemant, 123-45. Paris: Gallia Préhistoire Supplément 38

Viner, S., Evans, J., Albarella, U. \& Parker Pearson, M. 2010. Cattle mobility in prehistoric Britain: strontium isotope analysis of cattle teeth from Durrington Walls (Wiltshire, Britain). Journal of Archaeological Science 37, 2812-20

von den Driesch, A. 1976. A Guide to the Measurement of Animal Bones from Archaeological Sites. Cambridge MA: Peabody Museum

Wang, C., Schroeder, K.B. \& Rosenberg, N.A. 2012. A maximum-likelihood method to correct for allelic dropout in microsatellite data with no replicate genotypes. Genetics 192, 651-9

Warham, J.O. 2012. Mapping Biosphere Strontium Isotope Ratios Across Major Lithological Boundaries. Unpublished PhD thesis, University of Bradford

Western, D. \& Finch, V. 1986. Cattle and pastoralism: survival and production in arid lands. Human Ecology 14 (1), 77-94

Whittle, A. 1997. Moving on and moving around: Neolithic settlement mobility. In P. Topping (ed.), Neolithic landscapes, 15-31. Oxford: Neolithic Studies Group Seminar Papers 2

Whittle, A. 1999. The Neolithic period, c. 4000-2500/2200 bC. Changing the world. In J. Hunter \& I. Ralston (eds), The Archaeology of Britain, 58-76. London: Routledge

Whittle, A. 2010. The diversity and duration of memory. In D. Borić (ed.), Archaeology and Memory, 35-47. Oxford: Oxbow Books

Whittle, A., Healy, F. \& Bayliss, A. 2011. Gathering Time: Dating the Early Neolithic enclosures of southern Britain and Ireland. Oxford: Oxbow Books

Woodward, P.J. 1991. The South Dorset Ridgeway. Survey and Excavations 1977-84. Dorchester: Dorset Natural History \& Archaeological Society Monograph 8

Young, M. 1971. Fighting with Food. Leadership, Values and Social Control in a Massim Society. Cambridge: Cambridge University Press 


\section{RÉSUMÉ}

Rendez-vous dans la forêt: Chasseurs et agriculteurs à l'Anomalie' de Coneybury, de Kurt J. Gron, Peter Rowley-Conwy, Eva Fernandez-Dominguez, Darren R. Gröcke, Janet Montgomery, Geoff M. Nowell, et William P. Patterson

L'Anomalie' de Coneybury est une fosse du néolithique ancien située juste au sud-est de Stonehenge. Des excavations révélèrent un assemblage faunique unique par sa composition, consistant à la fois en espèces sauvages et domestiques ainsi qu'en de grandes quantités de céramique et d'outils en pierre, y compris une proportion substantielle de lames et lamelles. Nous présentons une série de nouvelles analyses d'isotopes du matériel faunique ainsi qu'une détermination de sexe par ADN ancien et reconsidérons les données fauniques publiées pour poser la question: Que s'est-il passé à Coneybury et qui était impliqué? Nous argumentons, en nous appuyant sur de multiples sources d'indices que Coneybury représente les vestigesmatériels d'un rassemblement organisé par une communauté régionale avec des participants venant de divers endroits. Un goupe parmi les présents a fourni du cerf au lieu, ou en plus, de bétail. Nous en concluons que le scénario le plus plausible est que ce groupe comprenait des chasseurs-cueilleurs locaux qui survivaient aux côtés des agriculteurs locaux.

\section{ZUSSAMENFASSUNG}

Ein Treffen im Wald: Jäger und Bauern an der Coneybury-,Anomalie”, von Kurt J. Gron, Peter RowleyConwy, Eva Fernandez-Dominguez, Darren R. Gröcke, Janet Montgomery, Geoff M. Nowell, und William P. Patterson

Die Coneybury-„Anomalie“ ist eine frühneolithische Grube, die unmittelbar außerhalb von Stonehenge gelegen ist. Ausgrabungen erbrachten ein Ensemble von Tierknochen, dessen Zusammensetzung einzigartig ist und sowohl aus Wild- wie aus Haustieren besteht, sowie eine große Anzahl an Keramik und Steinwerkzeugen, einschließlich einer substanziellen Anzahl an Klingen. In diesem Beitrag legen wir eine Reihe neuer Isotopenanalysen der Tierknochen gemeinsam mit Geschlechtsbestimmungen durch aDNA vor und bewerten die publizierten Daten zur Fauna neu, um die Frage zu stellen: Was geschah in Coneybury und wer war involviert? Auf Grundlage mehrerer Beweisführungslinien sprechen wir uns dafür aus, dass Coneybury die materiellen Hinterlassenschaften einer Zusammenkunft repräsentiert, die von der örtlichen Gemeinschaft organisiert wurde und Teilnehmer aus verschiedenen Regionen umfasste. Eine Gruppe unter den Anwesenden steuerte Hirsch statt oder zusätzlich zu Rind bei. Wir folgern, dass das wahrscheinlichste Szenario ist, dass diese Gruppe lokale Jäger-Sammler umfasste, die zeitgleich mit den lokalen Ackerbauern (über-) lebte.

\section{RESUMEN}

Un encuentro en el bosque: cazadores y agricultores en la "anomalía" de Coneybury por Kurt J. Gron, Peter Rowley-Conwy, Eva Fernandez-Dominguez, Darren R. Gröcke, Janet Montgomery, Geoff M. Nowell, y William P. Patterson

La “anomalía” de Coneybury es un fosa adscrita al Neolítico inicial situada al sureste de Stonehenge. Las intervenciones arqueológicas han recuperado un conjunto faunístico único en su composición, formado tanto por especies domésticas como salvajes, al igual que por una gran cantidad de cerámicas e industria lítica, incluyendo una sustancial proporción de láminas y laminitas. En este artículo presentamos un conjunto de nuevos análisis isotópicos de fauna, junto con la determinación del sexo a partir de los análisis de ADN y reconsideramos los datos faunísticos publicados para plantear la cuestión: ¿qué ocurrió en Coneybury y quién estuvo involucrado? En base a las múltiples líneas de evidencia, argumentamos que Coneybury representa los 
restos materiales de una reunión organizada por una comunidad regional, con participantes procedentes de distintas áreas. Uno de los grupos participantes aportó venados en lugar de, o además de, ganado. Concluimos que el escenario más probable es que este grupo estuviese compuesto por cazadores-recolectores que sobrevivieron junto a las comunidades de agricultores locales. 